\title{
Paleomagnetic directions of the Aso pyroclastic-flow and the Aso-4 co-ignimbrite ash-fall deposits in Japan
}

\author{
Junko Fujii ${ }^{1}$, Tadashi Nakajima ${ }^{1}$, and Hiroki Kamata ${ }^{2}$ \\ ${ }^{1}$ Geological Laboratory, Faculty of Education, Fukui University, Fukui 910-8507, Japan \\ ${ }^{2}$ Department of Earth Sciences, Faculty of Integrated Human Studies, Kyoto University, Kyoto 606-8501, Japan
}

(Received October 2, 2000; Revised September 3, 2001; Accepted September 4, 2001)

\begin{abstract}
The Aso pyroclastic-flow deposits, products of major Pleistocene volcanic eruptions in Japan, are divided into four eruptive units: Aso-1, Aso-2, Aso-3, and Aso-4 in ascending order. The paleomagnetic directions determined from welded tuff samples of these units, which are distributed near the source caldera in central Kyushu, are characteristic of the individual units and are all of normal polarity. The unit-mean directions for Aso-1 and Aso4 are similar to the direction of the present geomagnetic field. The direction for Aso- 2 is characterized by an unusually steep inclination, and that for Aso-3 by an unusually easterly declination. The mean VGP for the Aso-4 co-ignimbrite ash-fall deposits in Chubu, Tohoku, and Hokkaido is identical to those for subunits of the Aso-4 tephra: the Aso-4A welded tuff in Oita Prefecture, the lower part of the Ube volcanic ash layer in Yamaguchi Prefecture, and the distal ash-flow deposit in Miyazaki Prefecture. According to some evidences of volcanology, these subunits are supposed to have been deposited at the same time. The regional-mean directions for these subunits are almost the same as the directions expected for the overall-mean VGP $\left(A_{95}=1.3^{\circ}, N=42\right)$ located at $22.7^{\circ} \mathrm{W}, 83.8^{\circ} \mathrm{N}$. This indicates that its magnetization was acquired in a geomagnetic field dominated by the same dipole field (DF) component in all regions of the Japanese Islands; the DF pole is inferred to coincide with the overall-mean VGP.
\end{abstract}

\section{Introduction}

Aso caldera in central Kyushu, Japan, is one of the largest calderas in the world and covers an area of $380 \mathrm{~km}^{2}$. In late Pleistocene time, eruptions of voluminous pyroclastic flows occurred intermittently, resulting in formation of the caldera. The Aso pyroclastic-flow deposits are divided into four major units, i.e. Aso-1, Aso-2, Aso-3, and Aso-4 in ascending order (Ono et al., 1977). Welded tuffs of these units are widely distributed in central Kyushu, and are generally well suited for paleomagnetic research. Paleomagnetic measurements have been made on samples of these welded tuffs from many sites to determine precise geomagnetic field directions at the time of each eruption for the four major units. $\mathrm{K}-\mathrm{Ar}$ ages for Aso-1, Aso-2, Aso-3, and Aso-4 have been determined to be $266 \pm 14 \mathrm{ka}, 141 \pm 5 \mathrm{ka}, 123 \pm 6 \mathrm{ka}$, and $89 \pm 7 \mathrm{ka}$, respectively (Matsumoto et al., 1991).

Paleomagnetic studies of widespread late Pleistocene tephras have been carried out in order to construct geomagnetic charts for Japan in prehistoric times (Nakajima and Fujii, 1995a, b, 1998; Fujii and Nakajima, 1998; Fujii et al., 2000). Nakajima and Fujii (1995a) made paleomagnetic measurements on the Aira Tn tephra (AT), which erupted from Aira caldera at about $25 \mathrm{ka}$ and spread over distances of at least 1,400 km from southern Kyushu to Tohoku (Machida and Arai, 1983; Murayama et al., 1993). Using stable paleomagnetic directions from AT at 44 sites, charts

Copy right(c) The Society of Geomagnetism and Earth, Planetary and Space Sciences (SGEPSS); The Seismological Society of Japan; The Volcanological Society of Japan; The Geodetic Society of Japan; The Japanese Society for Planetary Sciences. of isogonic and isoclinic lines at its time of eruption were constructed. Fujii and Nakajima (1998) presented paleomagnetic directions for several other widespread tephras, including the Kikai-Akahoya, the Daisen-Kurayoshi, the Aso4, and the Sanbe-Kisuki tephras (Machida, 1999). Each tephra showed a characteristic paleomagnetic direction, presumably the geomagnetic field direction recorded at the time of eruption. The number of measurements is still too few, however, to discuss the geomagnetic field's exact configuration at the time each tephra was deposited over the Japanese Islands.

Co-ignimbrite ash-fall deposits of Aso-1, Aso-3, and Aso4 have been found in other regions of the Japanese Islands (Machida, 1991, 1999). The Aso-4 co-ignimbrite ash, especially, has been described by many stratigraphic researchers (e.g. Machida et al., 1985; Suzuki, 1993). In this study paleomagnetic samples from the Aso-4 co-ignimbrite ash were intensively collected. Preliminary reports on the paleomagnetism of the Aso pyroclastic-flow deposits and the Aso4 co-ignimbrite ash have been presented by Nakajima and Fujii (1998) and Fujii et al. (2000). In this paper, we will discuss the geomagnetic field at the time the Aso pyroclasticflow deposits were deposited, and especially when the Aso-4 tephra was deposited, on the basis of both new and previous paleomagnetic data.

\section{Samples}

We collected paleomagnetic samples in central Kyushu from welded tuffs of proximal facies of all of four major units: Aso-1, Aso-2, Aso-3, and Aso-4. In addition, the 

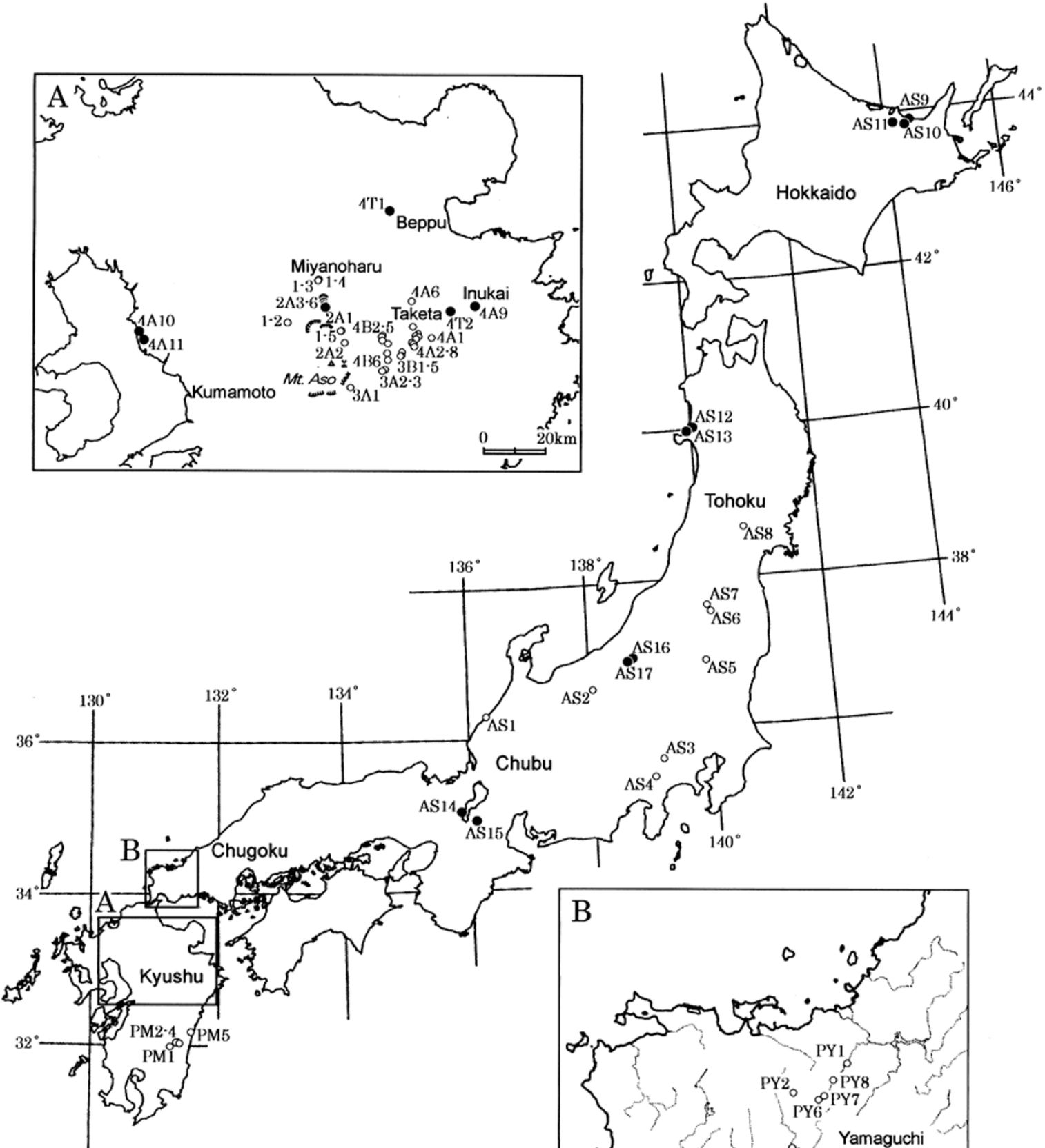

Fig. 1. Locality map showing paleomagnetic sampling sites. Solid and open circles show the sites for present and previous works (Nakajima and Fujii, 1998; Fujii et al., 2000), respectively. Samples from sites 1-1 to 1-5, 2A1 to 2A6, 3A1 to 3A3, 3B1 to 3B6, 4A1 to 4A11, 4T1 to 4T2, and 4B1 to 4B6 were collected from pyroclastic-flow deposits of Aso-1, Aso-2A, Aso-3A, Aso-3B, Aso-4A, Aso-4T, and Aso-4B, respectively. Those from sites AS1 to AS17, PM1 to PM5, and PY1 to PY13 were collected from Aso-4 co-ignimbrite ash-fall and Aso-4 distal ash-flow deposits in Miyazaki and Yamaguchi Prefecture, respectively.

Aso-4 ash-flow deposits of the distal facies were collected in southern Kyushu and Chugoku. Moreover, we collected the Aso-4 co-ignimbrite ash-fall deposits in Chubu, Tohoku, and Hokkaido (Fig. 1).

\subsection{Welded tuff samples of proximal facies of the Aso pyroclastic-flow deposits}

Aso-1, Aso-2, and Aso-3 are pyroxene rhyolite and andesite, while Aso-4 is hypersthene-hornblende rhyolite with small amounts of pyroxene-hornblende andesite (Ono et al., 1977). 


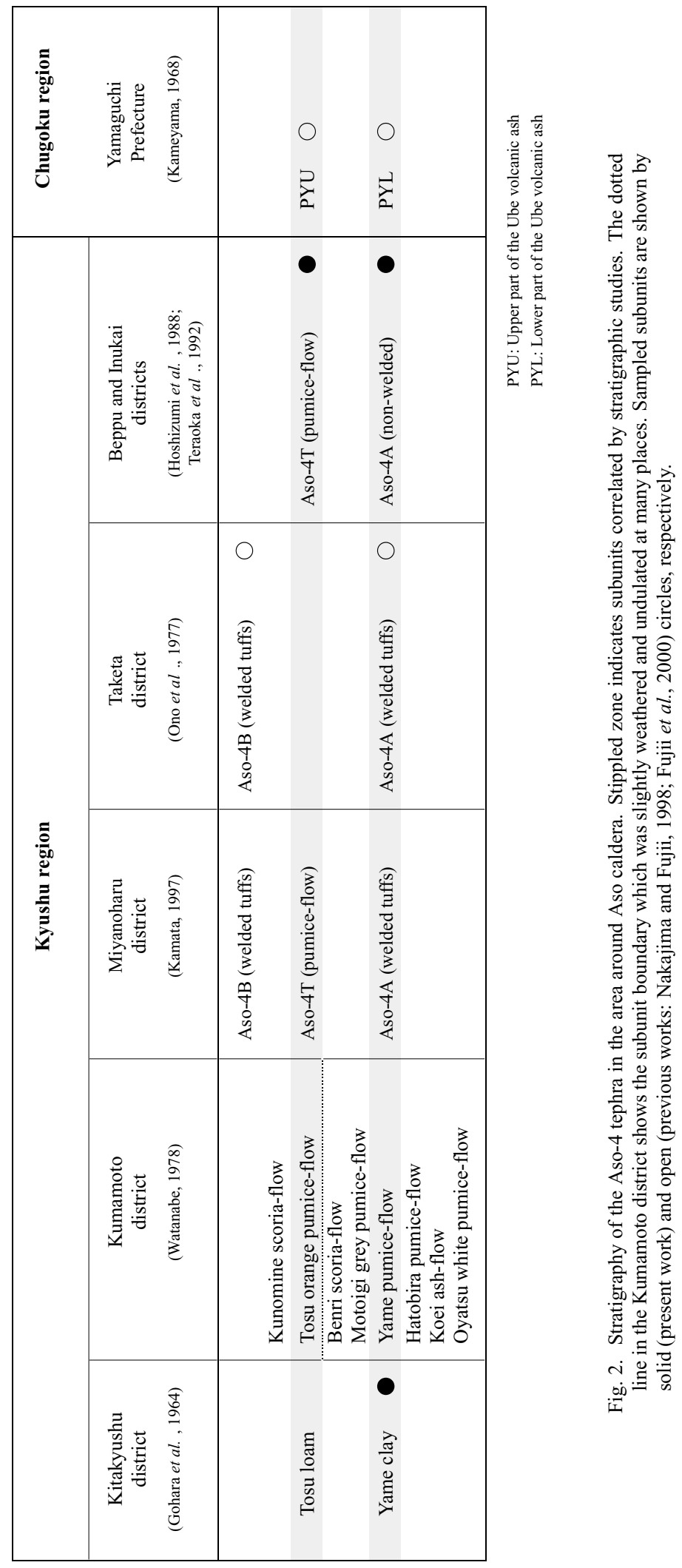


Aso-2, Aso-3, and Aso-4 are divided into two subunits (Aso-2A and Aso-2B in ascending order), into three subunits (Aso-3A, Aso-3B, and Aso-3C), and into two subunits (Aso-4A and Aso-4B), respectively. We collected oriented samples from all of the subunits, except Aso-2B and Aso$3 \mathrm{C}$ whose welded parts were rarely exposed in the surveyed district. Four sites of Aso-2A (2A3 to 2A6) were newly collected in the Miyanoharu district of Kumamoto Prefecture.

Ten hand samples were collected from each site, and were oriented with a magnetic compass. The orientation azimuth was corrected for local declination of the present geomagnetic field using values given in the isogonic chart for 1990.0 of the Geographical Survey Institute of Japan (1990). Two or more cylindrical specimens of $25 \mathrm{~mm}$ in diameter and 25 $\mathrm{mm}$ in height were drilled from each oriented sample, and a total of 20 to 25 specimens were obtained from each site.

\subsection{Samples of the Aso-4 pyroclastic-flow deposit}

The Aso-4 pyroclastic-flow deposits are divided into subunits in each district of the source area (Hoshizumi et al., 1988; Teraoka et al., 1990, 1992; Sakai et al., 1993; Kamata, 1997). For instance, Aso-4 is divided into eight subunits from the Oyatsu white pumice-flow to the Kunomine scoriaflow in the Kumamoto district, and is divided into three distinctive subunits (Aso-4A, Aso-4T, and Aso-4B) in the region northeast of Aso caldera. Figure 2 shows the stratigraphic relationship of subunits in the Aso-4 pyroclasticflow deposit. We collected paleomagnetic samples from the three horizons correlated to Aso-4A (11 sites: 4A1 to 4A11), Aso-4T (2 sites: 4T1 to 4T2) and Aso-4B (6 sites: 4B1 to 4B6) in central Kyushu. Samples from sites 4A1 to 4A8 and $4 \mathrm{~B} 1$ to $4 \mathrm{~B} 6$ are welded tuffs from Aso-4A and Aso-4B in the Taketa district, which were sampled by Nakajima and Fujii (1998). Those from site 4A9, from sites 4A10 to 4A11, and from sites $4 \mathrm{~T} 1$ to $4 \mathrm{~T} 2$, which were newly sampled, are non-welded tuff (Aso-4A) in the Inukai district, clay (the Yame clay) in the Kitakyushu district, and pumice-flow deposit (Aso-4T) in the Beppu district, respectively.

The Aso-4 distal ash-flow deposit in the Chugoku region's Yamaguchi Prefecture is named the Ube volcanic ash layer. The lower and upper parts (PYL and PYU) correspond to Aso-4A and Aso-4T in Kyushu, respectively (Gohara et al., 1964; Kameyama, 1968; Watanabe, 1978; Kamata, 1997). Paleomagnetic samples were collected from both PYL (9 sites) and PYU (11 sites) of the Ube volcanic ash layer (Fujii et al., 2000).

Samples from sites PM1 to PM5 were collected from the Aso-4 distal ash-flow deposits in Miyazaki Prefecture (Nakajima and Fujii, 1998). Here the ash-flow deposits (PM) are 20 to $100 \mathrm{~cm}$ thick, and are situated within the Hyuga loam (Endo and Suzuki, 1986).

2.3 Samples of the Aso-4 co-ignimbrite ash-fall deposit

Machida et al. (1985) discovered a distal ash layer at several localities in Japan with similar petrographic and chemical properties to those of the Aso-4 pyroclastic-flow deposit, and interpreted it as a co-ignimbrite ash-fall deposit from the Aso- 4 eruption. The ash, named the Aso- 4 ash, is a vitric, fine-grained volcanic ash consisting of bubblewalled glass shards, and brown hornblende and orthopyroxene (bronzite) mafic phenocrysts; these characteristics are similar to those of Aso-4. The Aso-4 ash mantles extensive regions from Kyushu to Hokkaido, and is also recognized in piston cores from the Sea of Japan and the northwest Pacific Ocean (Machida and Arai, 1983). The Aso-4 ash thus provides a very important datum plane within the late Pleistocene sequence of Japan and surrounding areas.

The Aso-4 co-ignimbrite ash-fall deposits (AS) were sampled at 17 sites in wide areas from Chubu to Hokkaido (Fig. 1). Samples at sites AS1 to AS8 were described in Nakajima and Fujii (1998). Samples at sites AS9, AS10, and AS11, in the northeast part of Hokkaido facing the Sea of Okhotsk, were collected from ash beds about $15 \mathrm{~cm}$ thick. The ash beds at sites AS9 and AS11 are in a sandy gravel; the ash bed at site AS10 is overlain by the Kutcharo pyroclastic-flow deposit II/III (Okumura, 1991). Samples at sites AS12 and AS13 in Akita Prefecture were collected from ash beds about 5 and $15 \mathrm{~cm}$ thick, respectively, in the marine Katanishi Formation (Shiraishi et al., 1992). Samples at sites AS14 and AS15 in Shiga Prefecture were collected from ash beds 4 to $8 \mathrm{~cm}$ in thickness within a fluvial terrace deposit (Kimura et al., 1998). Samples at sites AS16 and AS17 in Niigata Prefecture were collected from ash beds 1 to $5 \mathrm{~cm}$ in thickness within the Kaisaka Loam Formation (Watanabe et al., 1999).

From the Aso-4 distal ash-flow and co-ignimbrite ash-fall deposits, twelve to twenty oriented samples were collected at each site using the sampling method of inserting $24 \mathrm{~mm}$ plastic cubes into the stratum. At the bottom of the cube, a hole $1 \mathrm{~mm}$ in diameter was made for air escape. The sampling apparatus consists of a cylinder-like block with a hole to insert the plastic cube, a piston rod, a board to fix the block, and a magnetic compass (Hirooka, 1988).

\section{Paleomagnetic Measurements}

Measurements of a specimen's remanent magnetization were made with a flux-gate spinner magnetometer (Natsuhara Giken Co., Model SMM-85). Alternating field demagnetization (AFD) was carried out progressively in more than 5 steps up to $70 \mathrm{mT}$ for all samples with a two-axis tumbler contained in a three-layer mu-metal shield.

The AFD experiments on samples of the Aso-4 co-ignimbrite ash-fall (Fig. 3A) and distal ash-flow (Fig. 3B) deposits show that after removal of a small unstable component by 5 or $10 \mathrm{mT}$, the characteristic magnetization decayed toward the origin of the orthogonal projection plots. The characteristic magnetizations of the welded tuff specimens were also very stable to AFD. The specimen magnetizations at 12 sites (4B1, 4B3, 4A3, 4A5, 4A6, 3B5, 3B6, $2 \mathrm{~A} 3,2 \mathrm{~A} 4,1-2,1-3,1-4)$ decayed linearly toward the origin of the orthogonal projection plots during AFD. Although the magnetizations of samples from the other welded-tuff sites included unstable components, the unstable components were removed by AFD with peak fields of less than $30 \mathrm{mT}$ (Fig. 3C).

Thermal demagnetization (ThD) up to $580^{\circ} \mathrm{C}$ was carried out progressively in 7 steps on three pilot specimens from each welded tuff site. The Aso-4 co-ignimbrite ash-fall and distal ash-flow samples could not be subjected to ThD because they were held in plastic cubes with a melting temperature of $160^{\circ} \mathrm{C}$. The specimens were heated in air using a noninductively wound electric furnace. The stray field dur- 
A

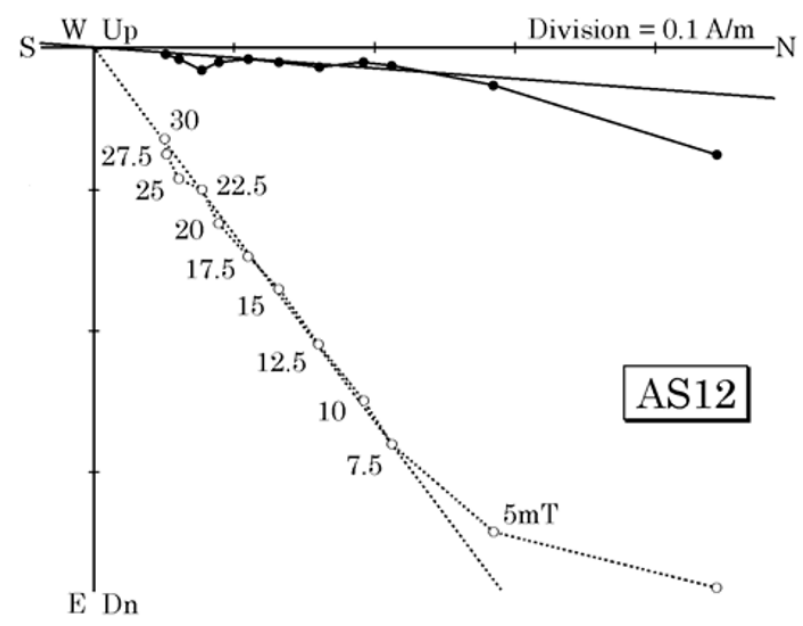

C

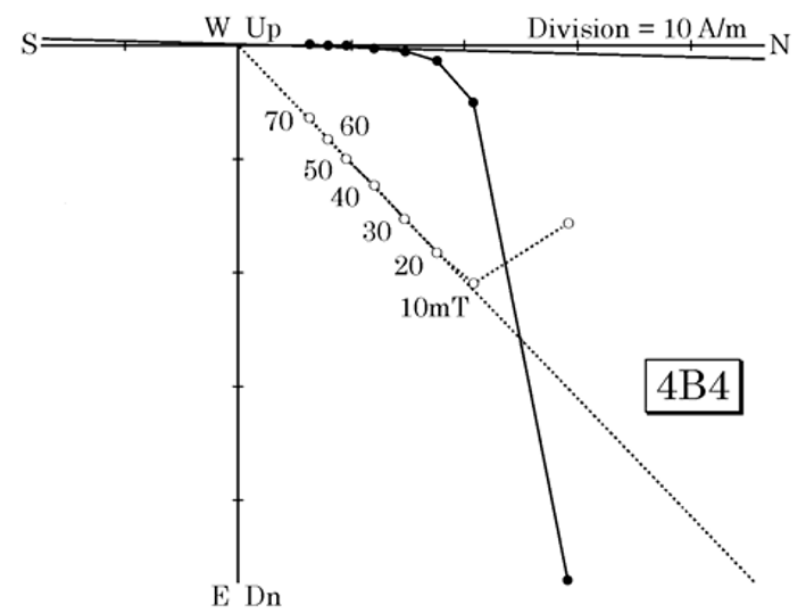

B

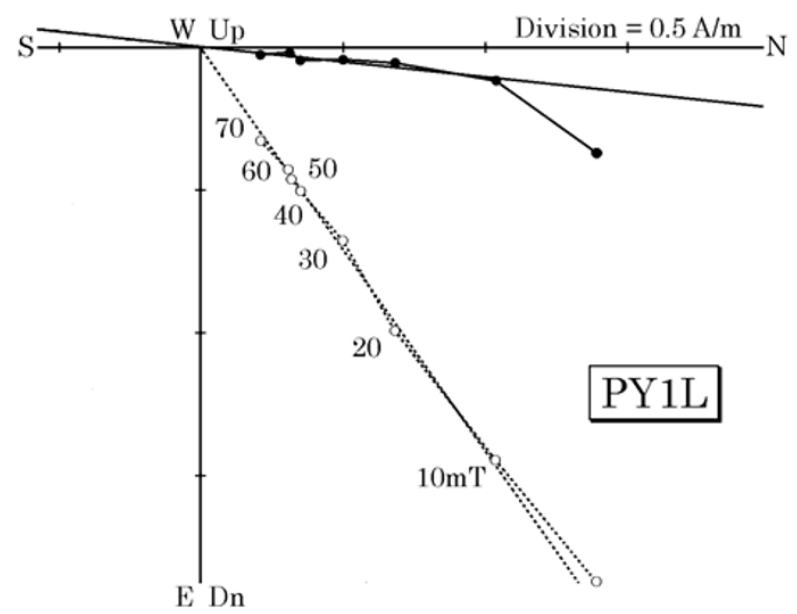

D

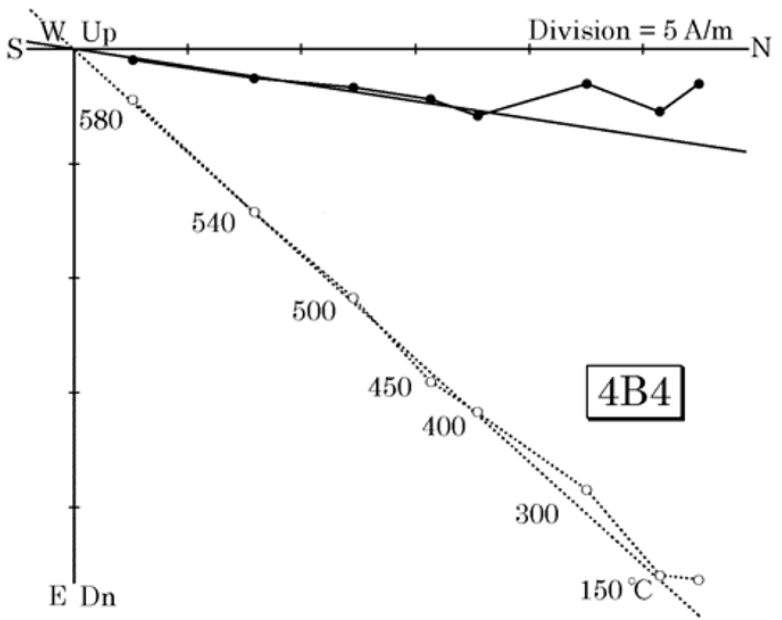

Fig. 3. Examples of orthogonal plots of AFD data for the Aso-4 co-ignimbrite ash-fall deposit (A), a distal ash-flow deposit (B), and a proximal welded tuff (C); ThD data for a welded tuff (D). Solid and open symbols represent projection onto horizontal and vertical planes, respectively.

ing the cooling cycle was reduced to less than $10 \mathrm{nT}$ using a cylindrical three-layer mu-metal shield. The ThD instrument and thermo-controller (Model DEM-8602) were provided by Natsuhara Giken. In order to check thermal alteration of the magnetic minerals, susceptibility measurements of the specimens were made at each demagnetization level using a susceptibility meter (Bartinton Instruments Ltd., Model MS2B).

Unstable components were removed by demagnetization at temperatures below $400^{\circ} \mathrm{C}$ (Fig. 3D). Rapid decreases in the magnetic intensity were observed at low temperature levels for specimens at five sites: 4A1, 4A2, 4A3, 4A8, and 1-5 (Fig. 4). The rapid decreases likely indicate the presence of secondary magnetic minerals such as goethite and pyrrhotite. The characteristic directions of these specimens, however, were considered to be primary magnetizations because these directions are the same as those obtained from other specimens without the rapid intensity decrease at low temperatures. At the other sites, the specimens had high blocking temperatures which were mostly removed by $\mathrm{ThD}$ to $580^{\circ} \mathrm{C}$ (Fig. 4). This evidence suggests that the magnetic minerals carrying the characteristic magnetization are mainly magnetites or titanomagnetites with low titanium content. Since the change in susceptibility at each demagnetization level was less than $10 \%$ of the value before demagnetization, the alteration of the magnetic minerals by heating is presumed to be minor.

Directions of the primary magnetic components were computed using principal component analysis (Kirschvink, 1980); three-dimensional least-squares fits were made of the demagnetization data with the fitted line forced to include the origin (anchored). Site-mean directions were calculated using the AFD data because the same primary magnetic component was detected by both demagnetization methods.

New results of the paleomagnetic measurements are shown in Table 1. The ash samples were collected only from horizontal strata. Eutaxitic structures of flattened obsidian lenses in the welded tuffs are mostly horizontal, and there is no evidence of significant tilting. Therefore, no tilt correction was made to the magnetic directions in Table 1. The 

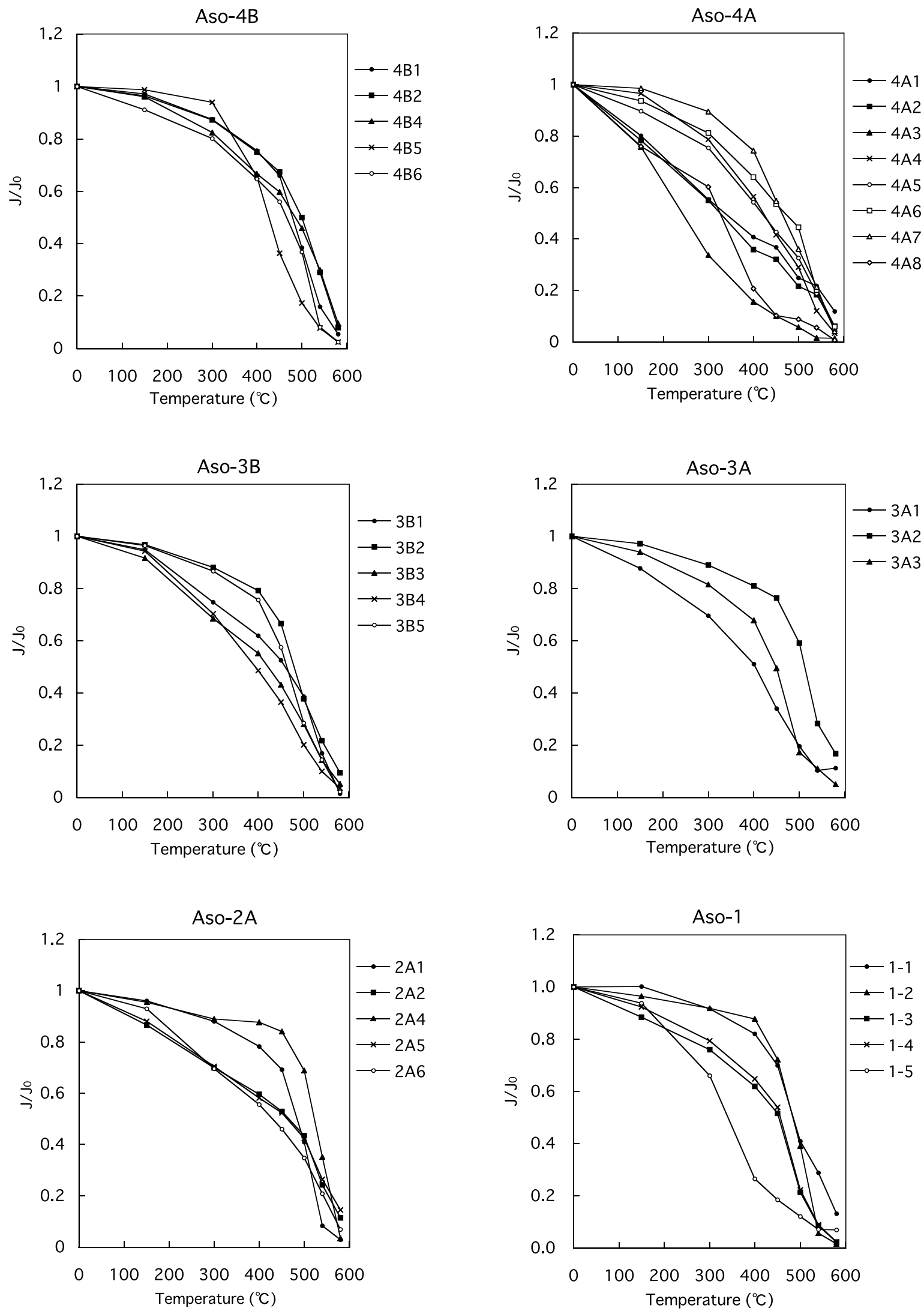

Fig. 4. ThD curves where relative intensity is plotted against demagnetizing temperature. 
J. FUJII et al: PALEOMAGNETIC DIRECTIONS OF THE ASO-4 TEPHRA

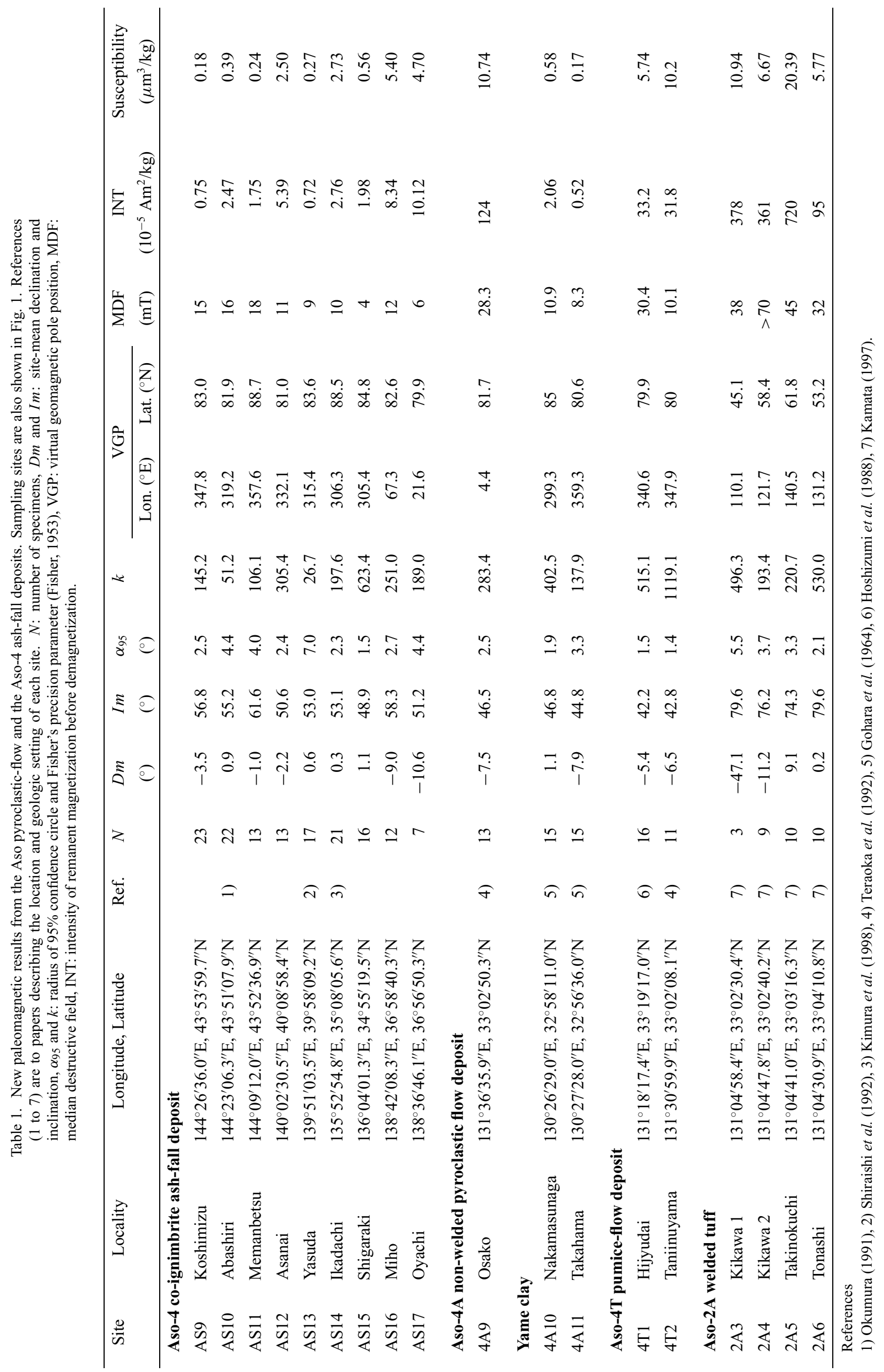




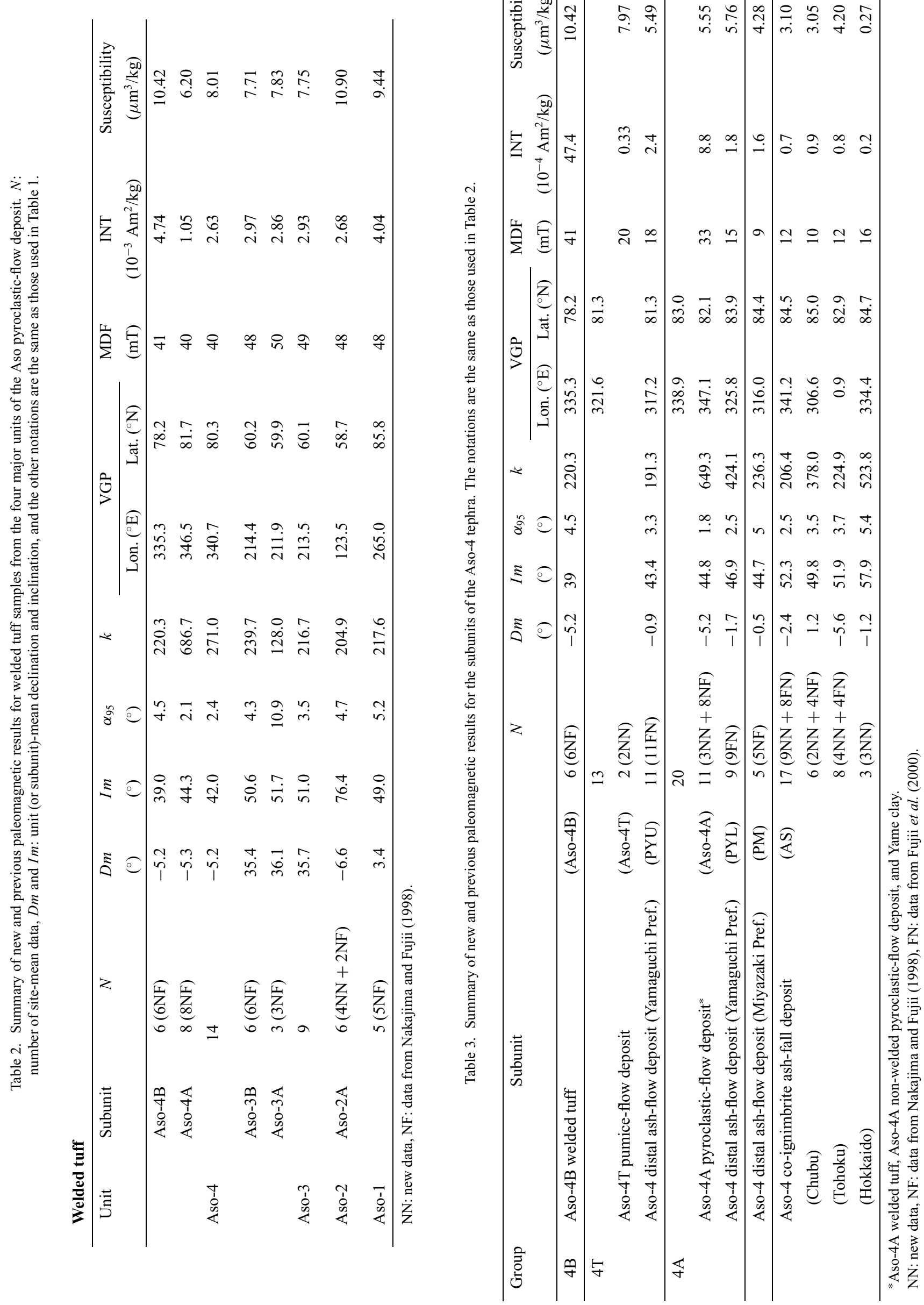

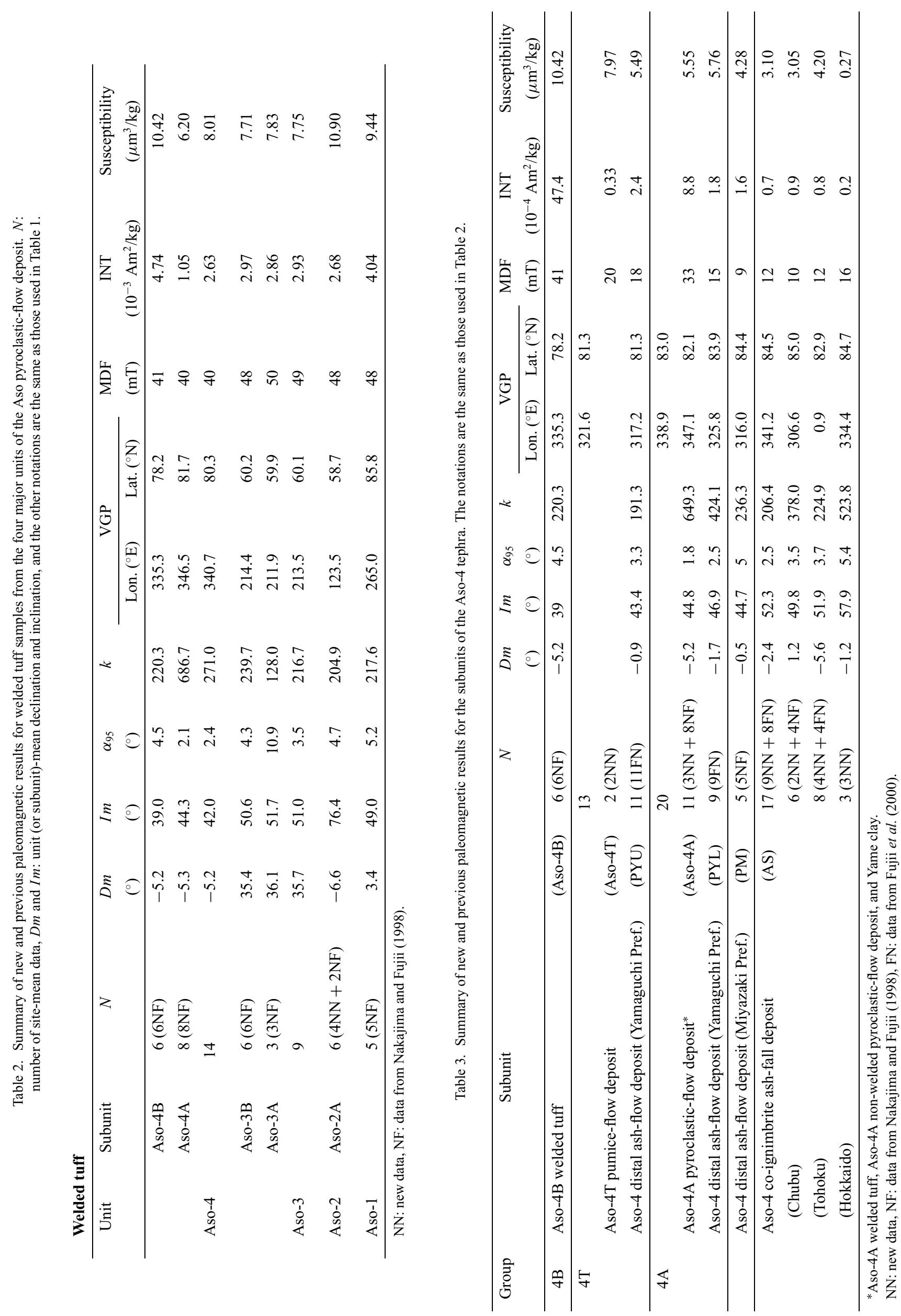

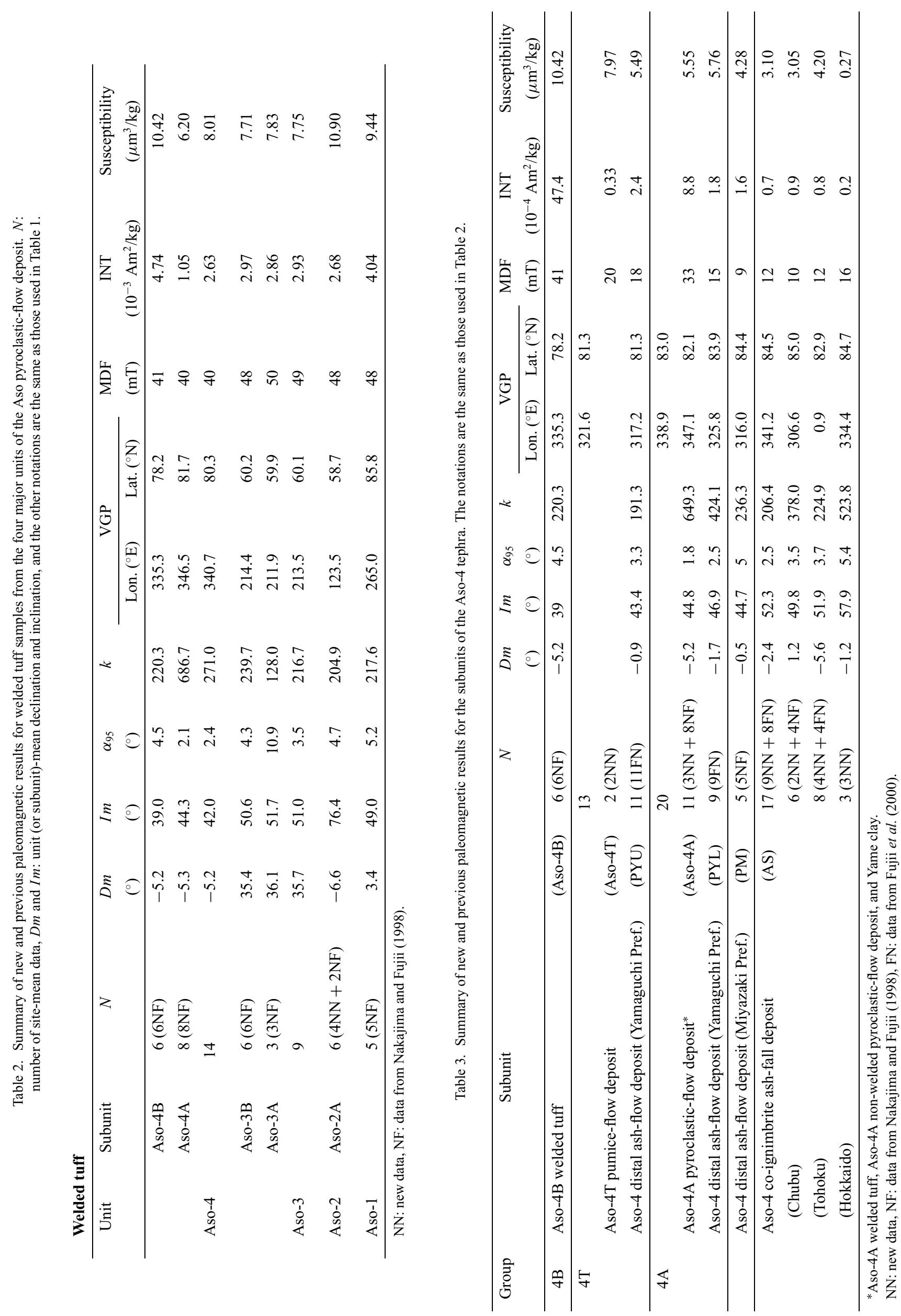

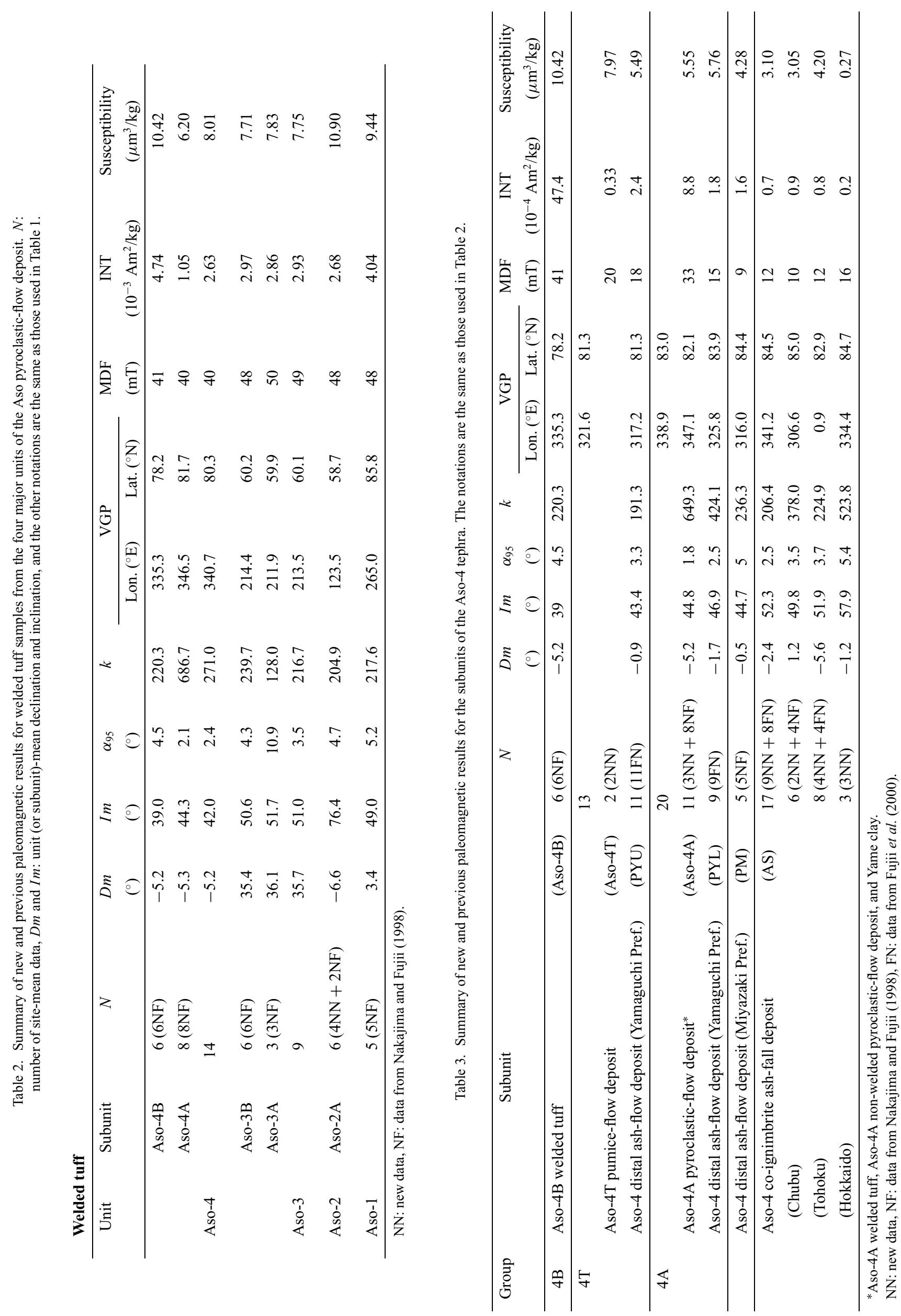

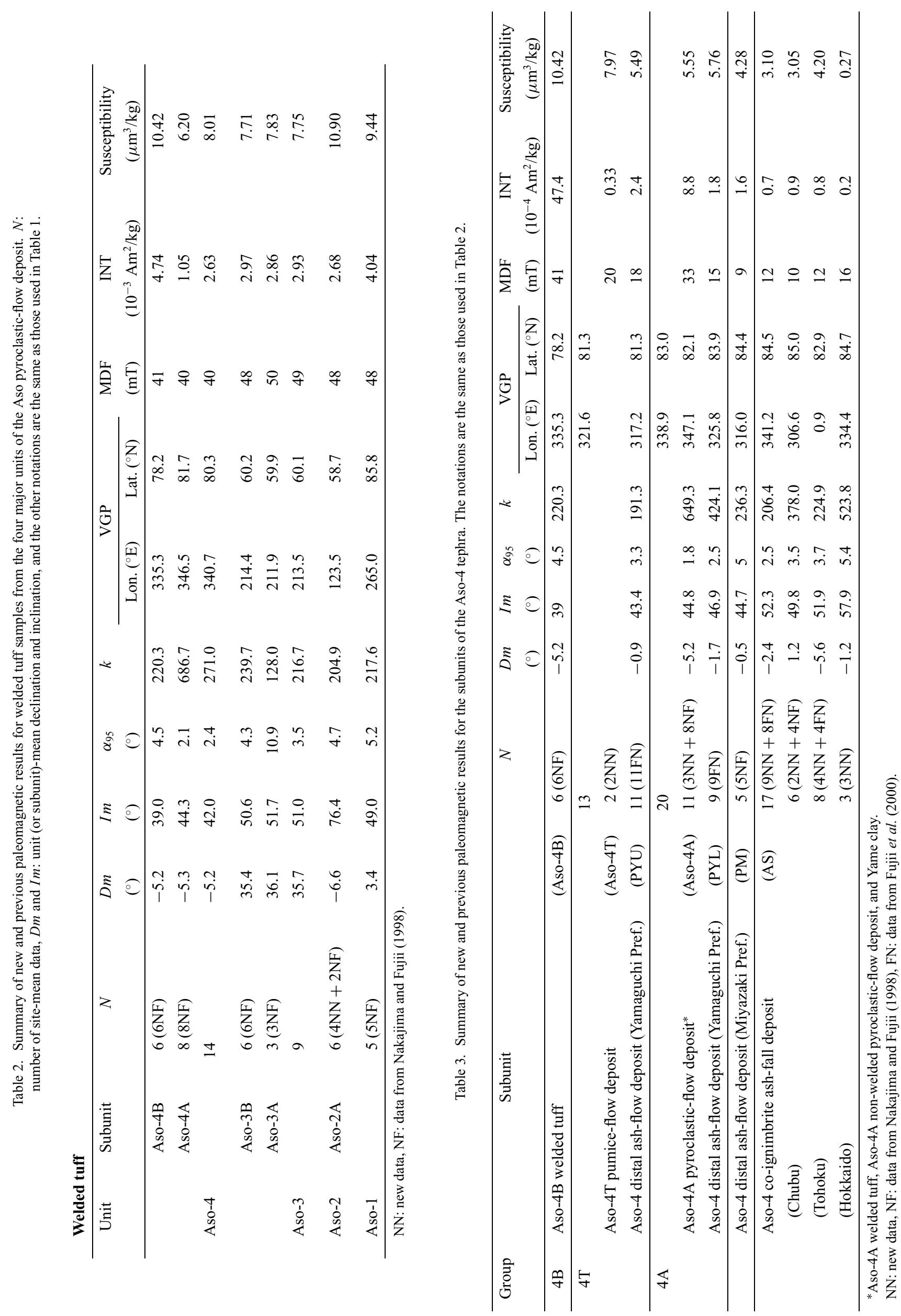

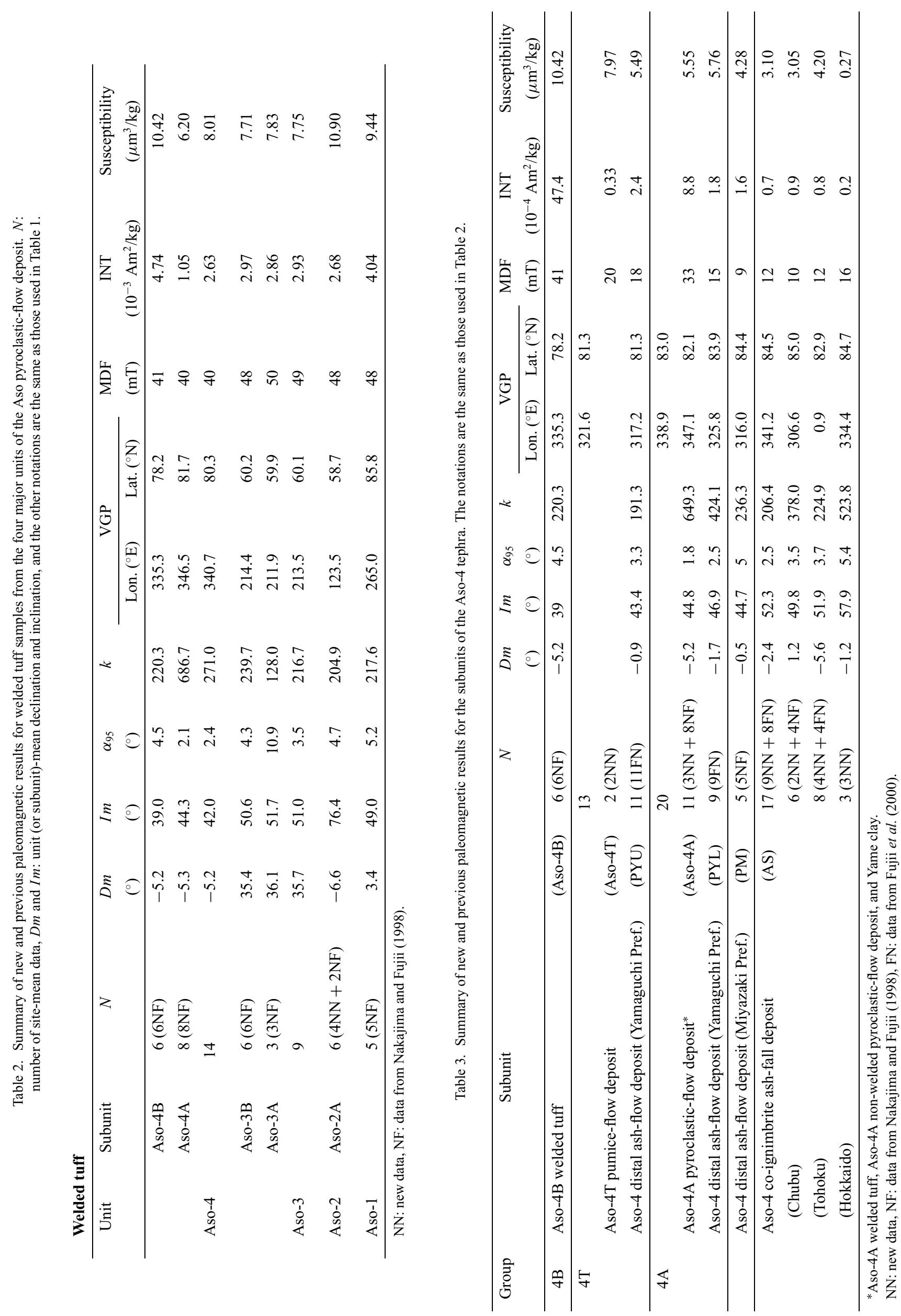

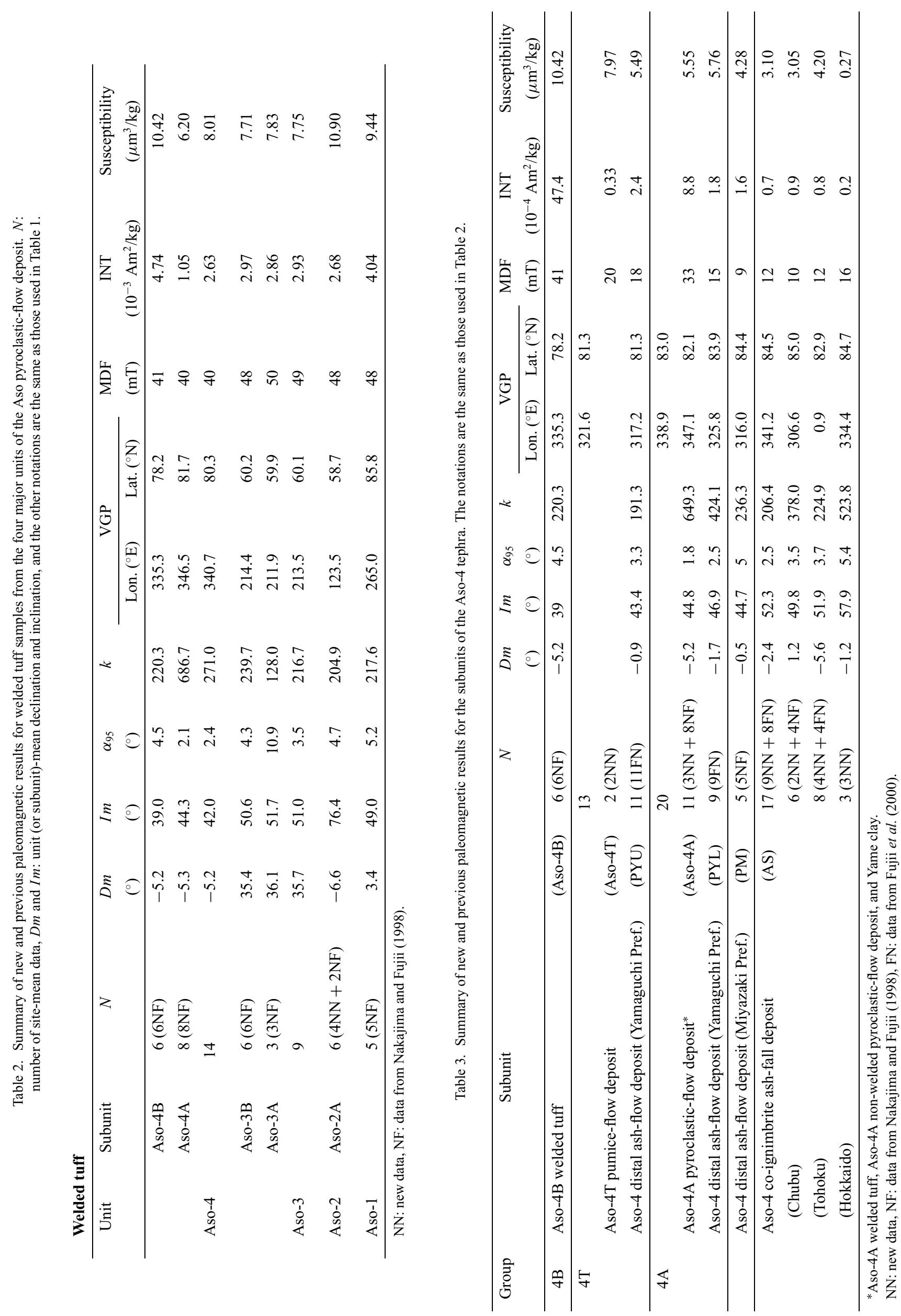

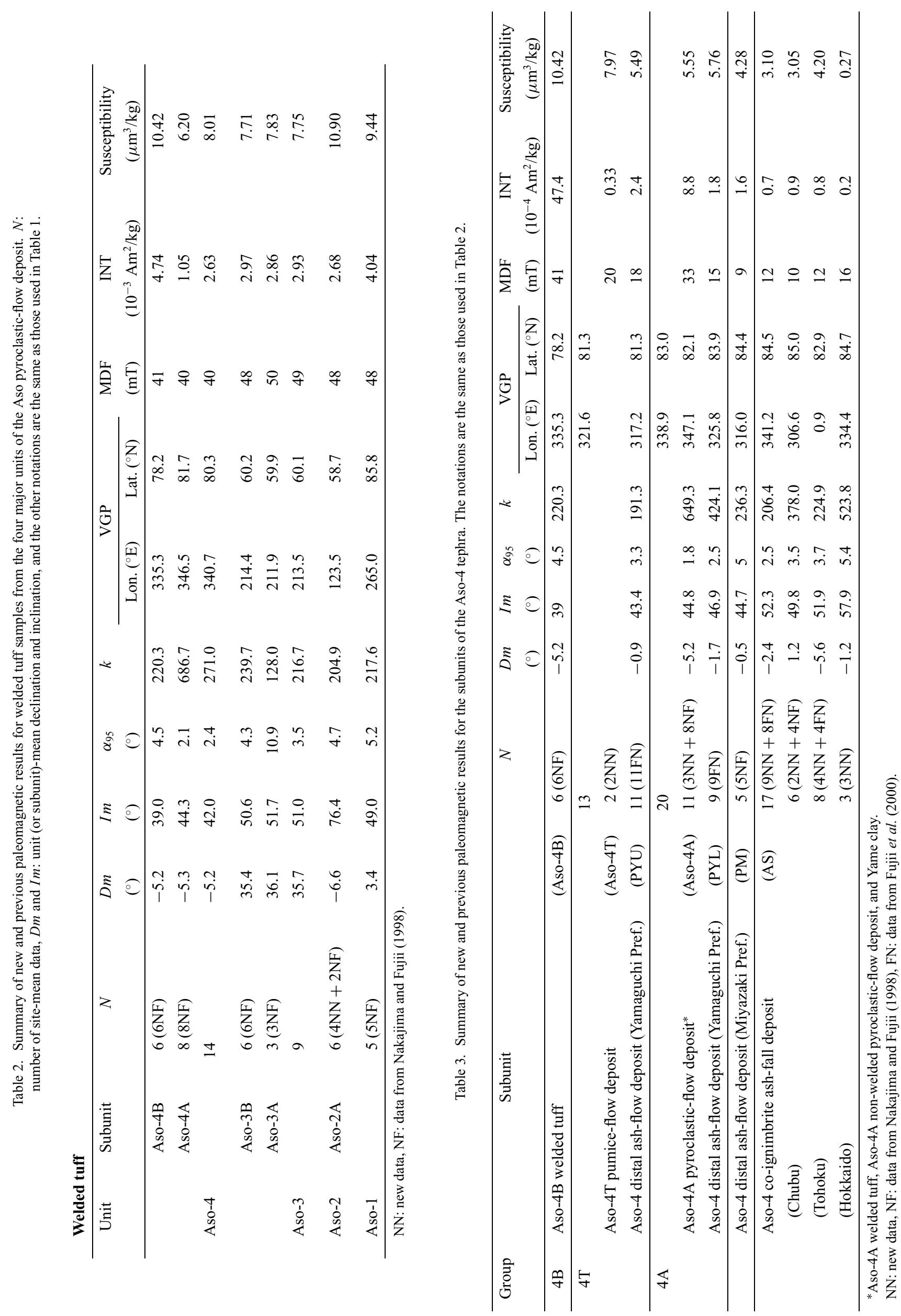

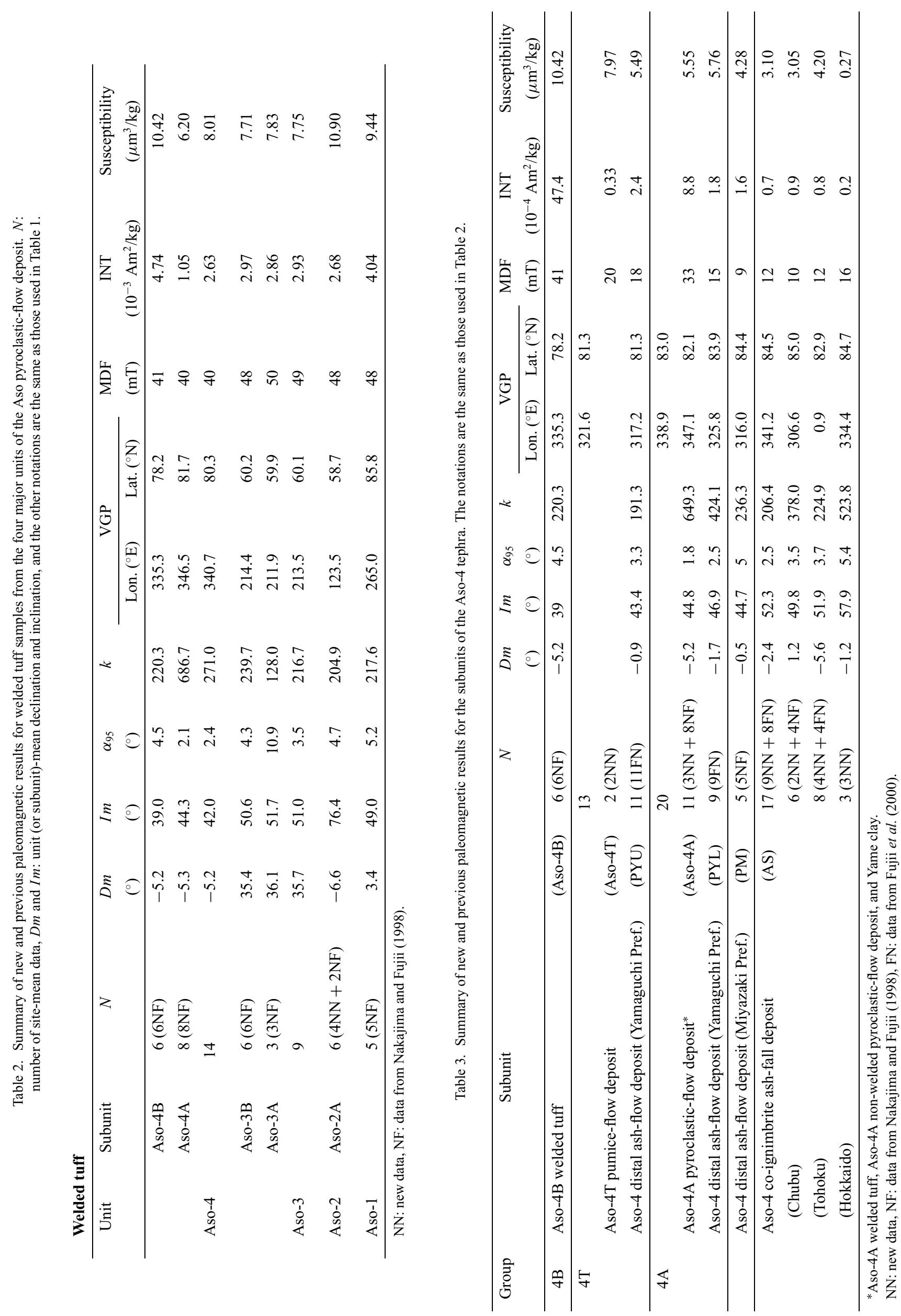

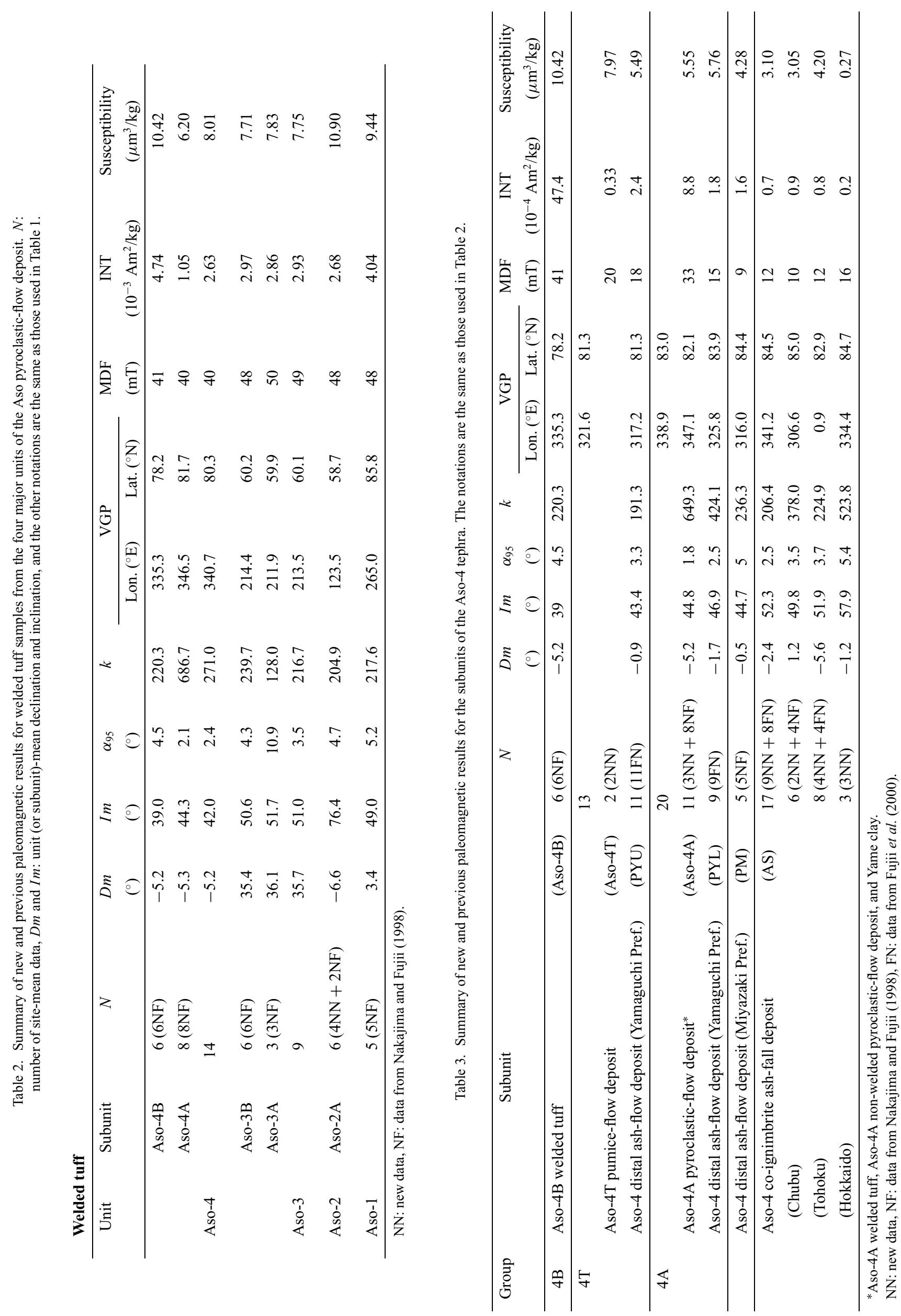

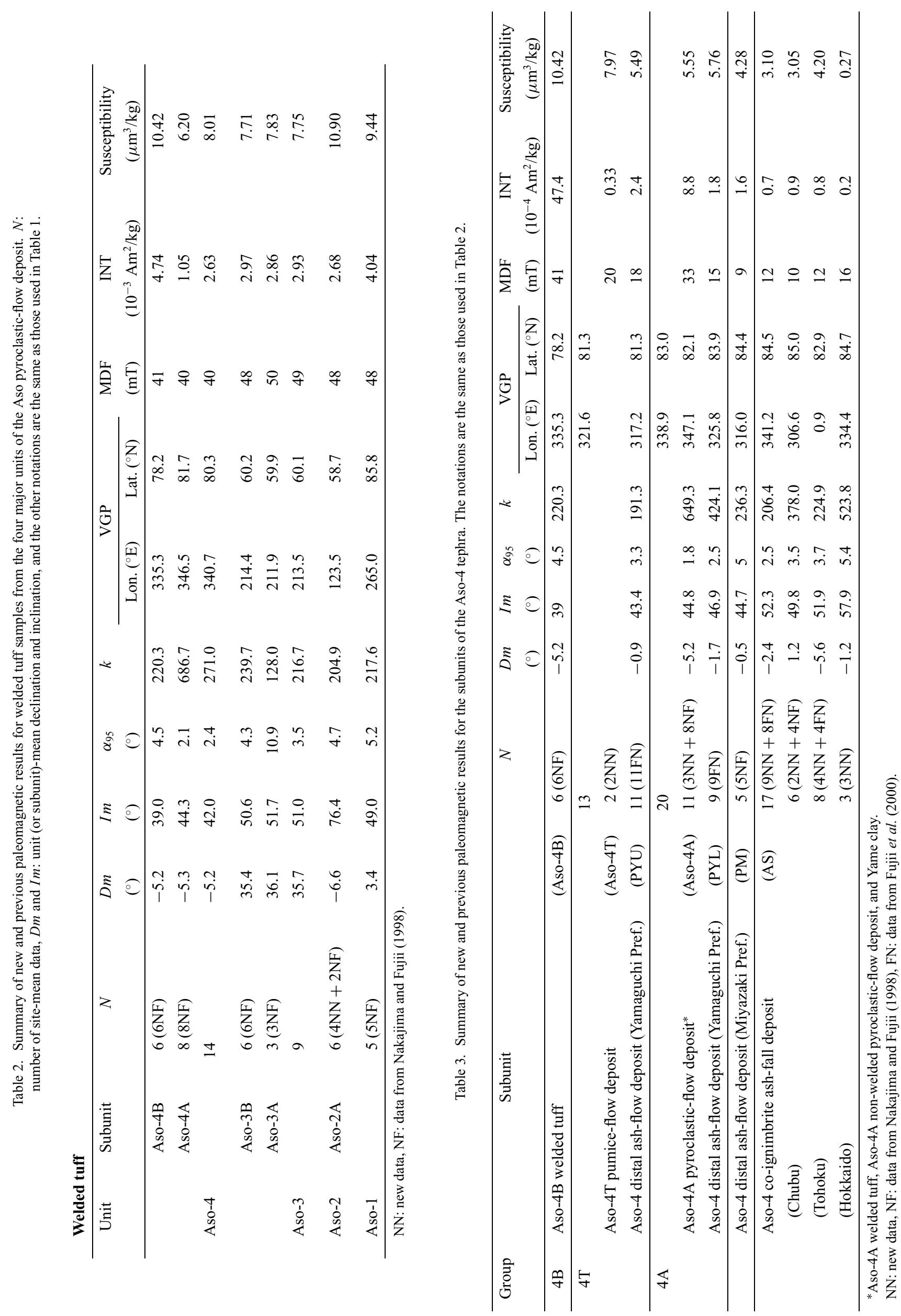


unit- and subunit-means for Aso-1 to Aso-4 welded tuffs and the Aso-4 tephra were calculated from all site-mean data including previous data (Nakajima and Fujii, 1998; Fujii et al., 2000) and are tabulated in Tables 2 and 3, respectively.

Subunit-mean susceptibilities are distributed in a comparatively narrow range between 3.1 and $10.9 \mu \mathrm{m}^{3} / \mathrm{kg}$. Intensities of magnetization for welded tuff specimens are on the order of $10^{-3} \mathrm{Am}^{2} / \mathrm{kg}$, and for ash samples on the order of $10^{-5}$ to $10^{-4} \mathrm{Am}^{2} / \mathrm{kg}$. In addition, mean destructive fields (MDFs) for the proximal welded tuffs (40 to 50 $\mathrm{mT}$ ) are higher by about $30 \mathrm{mT}$ than those for the Aso-4 co-ignimbrite ash-fall and distal ash-flow samples.

\section{IRM Acquisition and ThD of a Three-Compo- nent IRM}

Magnetic minerals contained in the welded tuff specimens are likely to be magnetites or titanomagnetites on the basis of the ThD results. Since ThD experiments were not performed on the ash samples, it is not certain what magnetic minerals are in the ash samples. Progressive acquisition of isothermal remanent magnetization (IRM) and ThD of a three-component IRM (Lowrie, 1990), therefore, were investigated to identify the ferromagnetic mineral content in

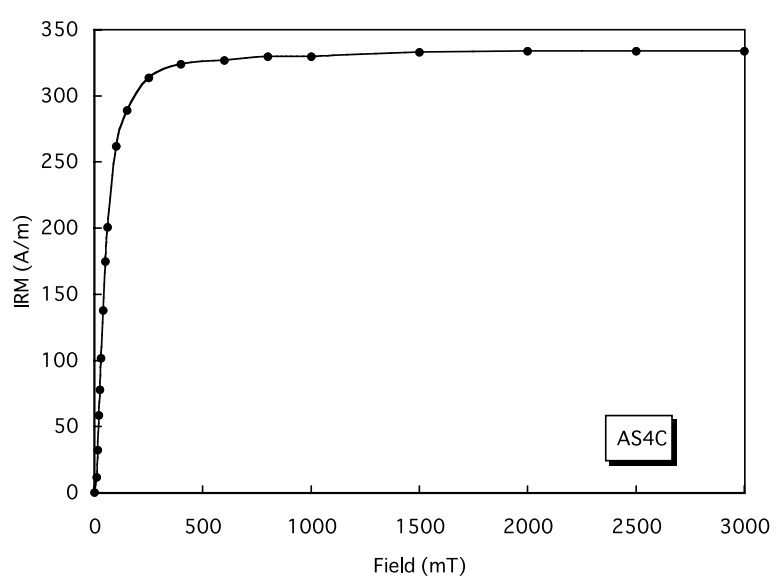

Fig. 5. Progressive acquisition of IRM in an ash sample.

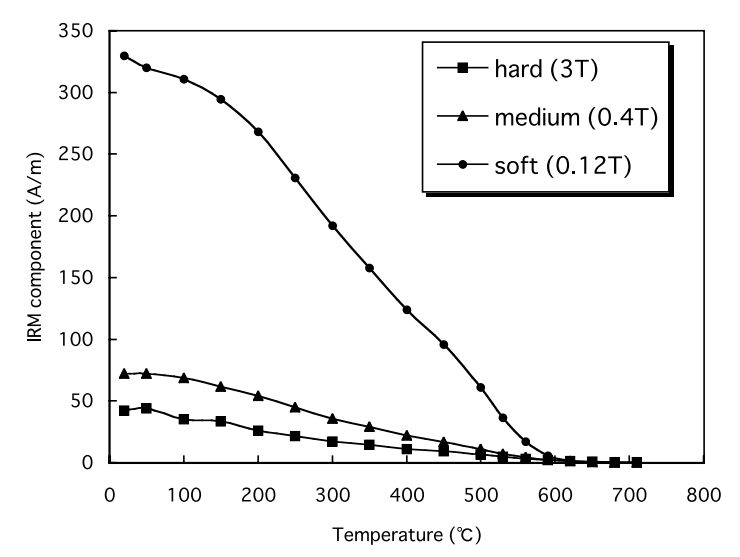

Fig. 6. Example of ThD of a three-component IRM produced by applying different DC fields $(3,0.4$, and $0.12 \mathrm{~T})$ to each of the three perpendicular sample axes. the ash samples.

For the IRM experiments, one sample from each site was arbitrarily chosen after AFD. Because they are unconsolidated and readily disintegrate, the ash samples were held in plastic cubes, which melt at about $160^{\circ} \mathrm{C}$. We prepared synthetic specimens using ash samples and plaster of Paris for ThD of the induced IRM.

The IRM acquisition experiments were carried out using a pulse magnetizer (Magnetic Measurements Ltd., Model MMPM10) in magnetic fields with intensities up to $3 \mathrm{~T}$. A three-component IRM was produced by applying a different DC field $(3,0.4$, and $0.12 \mathrm{~T})$ to each of the three perpendicular axes of the specimen with the pulse magnetizer. The acquisition and ThD curves of the IRM components for all specimens show similar features. The smooth IRM acquisition curves rise steeply up to $100 \mathrm{mT}$, and reach saturation by $400 \mathrm{mT}$ (Fig. 5). The ThD of each IRM component is plotted separately in Fig. 6. The ThD curves show that the soft $(<0.12 \mathrm{~T})$ coercivity fraction is the largest, and that the medium $(0.12-0.4 \mathrm{~T})$ and hard $(0.4-3 \mathrm{~T})$ fractions are minor. The soft coercivity fraction was demagnetized smoothly to zero by $580^{\circ} \mathrm{C}$, indicating that the specimens' magnetic mineralogy is also dominated by magnetites and titanomagnetites.

\section{Paleomagnetic Directions}

\subsection{Welded tuffs of the Aso pyroclastic-flow deposits}

Magnetic directions of the welded tuff samples are grouped tightly for each unit or subunit, and are all of normal polarity. The unit-mean directions of Aso-1 and Aso-4 (Table 2) are near the present geomagnetic field direction $\left(D=-6^{\circ}, I=46^{\circ}\right)$. The unit-mean directions of Aso-2 and Aso-3, however, are $>30^{\circ}$ away from the present geomagnetic field direction. The inclination of the Aso-2 direction is very steep, and the declination of the Aso-3 direction is more easterly. It appears that the distinctive directions of Aso-2 and Aso-3 could be useful in identifying these tephras. The steep inclination of Aso-2 has also been pointed out by Shibuya (personal communication). When the magnetic directions are compared between subunits, the inclination of Aso-4A is steeper than that of Aso-4B by 5 degrees, although such a difference is not seen between directions for the subunits of Aso-3: Aso-3A and Aso-3B.

Since geomagnetic excursions and short-term geomagnetic events between the Aso-1 (266 ka) and the Aso-4 (89 ka) eruptions have been reported in previous paleomagnetic studies (Kawai et al., 1971; Hyodo et al., 1993; Hyodo and Minemoto, 1996; Hyodo, 1999), we expected that such geomagnetic events like the Blake and Biwa II events would be recorded by these welded tuffs. However, we did not find any directions indicating geomagnetic excursions or short events with reversed polarity in the welded tuffs.

\subsection{The Aso-4 tephra}

The Aso-4 tephra consists of proximal pyroclastic-flow deposits (Yame clay, Aso-4A, Aso-4T, and Aso-4B), distal ash-flow deposits (PM, PYL, and PYU), and co-ignimbrite ash-fall deposits (AS). The sampled subunits of the Aso4 pyroclastic-flow deposit in the area around the source caldera are divided into three stratigraphic groups (Fig. 2): 4A (Aso-4A, Yame clay, and PYL), 4T (Aso-4T and PYU), 
and 4B (Aso-4B). Stratigraphic correlations of AS and PM with subunits in the source area were not established in previous studies.

The 'geographically corrected site-mean directions' (corrected directions) cluster tightly in each stratigraphic group (Fig. 7) and support the stratigraphic correlation within each group. The corrected directions are calculated from their virtual geomagnetic poles (VGPs) at a reference point in Aso caldera $\left(131^{\circ} \mathrm{E}, 33^{\circ} \mathrm{N}\right)$. The group-mean VGP of $4 \mathrm{~A}$ is identical to the subunit-mean VGPs of AS and PM (Table 3). To emphasize the difference between other groups, groupmean corrected directions of 4A, 4T, and 4B and subunitmean corrected directions of AS and PM are shown in Fig. 8. The corrected directions of $4 \mathrm{~A}, \mathrm{AS}$, and PM are identical to one another with overlapping $95 \%$ confidence circles. The agreement of the corrected directions indicates that AS and PM were deposited at approximately the same time as 4A. This correlation with the co-ignimbrite ash-fall deposit (AS) is consistent with the fact that 4A covers an extensive area, and is supposed to be the product of the culminate phase of

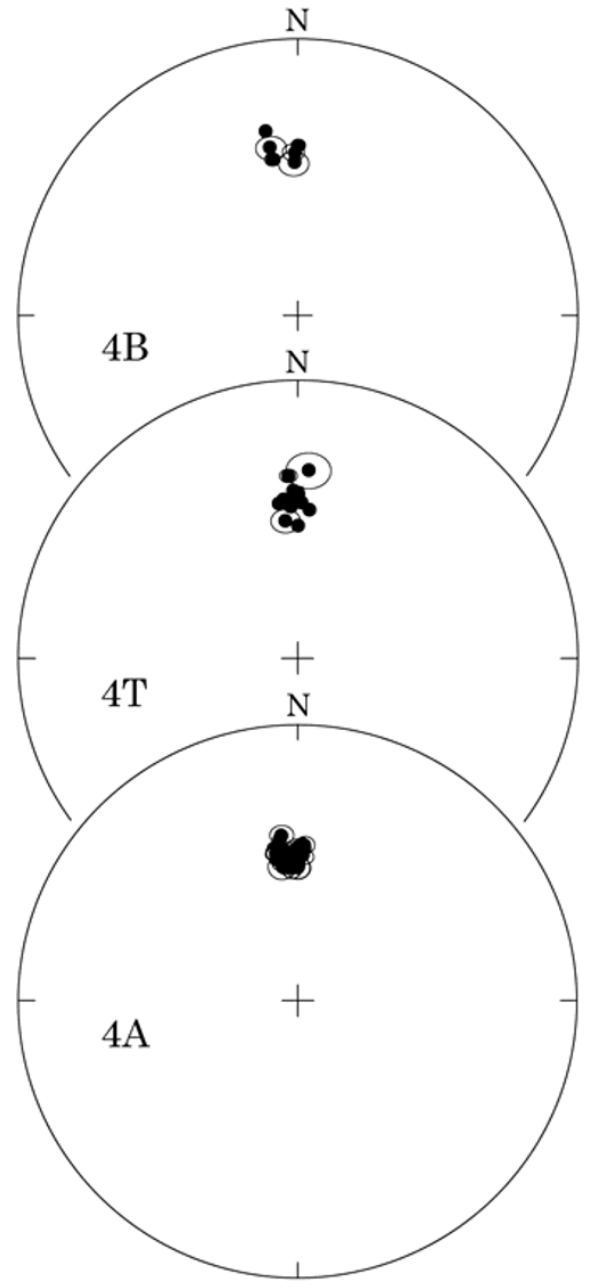

Fig. 7. Equal-area projection of 'geographically corrected site-mean directions' (corrected directions) and 95\% confidence circles (lower hemisphere) for the Aso-4 pyroclastic-flow deposit. The corrected directions are calculated from their virtual geomagnetic poles (VGPs) at a reference point in Aso caldera $\left(131^{\circ} \mathrm{E}, 33^{\circ} \mathrm{N}\right)$. 4B: Aso-4B, 4T: Aso-4T and PYU, 4A: Aso-4A, Yame clay, and PYL. the Aso-4 eruption (Watanabe, 1978).

In the area around the source caldera, the group-mean corrected inclination of $4 \mathrm{~A}$ is steeper by 6.7 degrees than that of $4 \mathrm{~B}$, and by 3.8 degrees than that of $4 \mathrm{~T}$. The inclination differences, in which the lower one is steeper than the upper, were observed even at the sites collected samples from both the lower (4A) and the upper (4T) groups in Yamaguchi Prefecture (PY1, PY2, PY4, PY5, PY8, PY11, PY12; Fujii et al., 2000). And the inclination differences between $4 \mathrm{~A}$ and $4 \mathrm{~B}$ were also observed in the limited area of the Taketa district (Nakajima and Fujii, 1998). If the inclination differences were significant, it may be assumed that the differences observed in the limited area originated from stratigraphic time gaps rather than being caused by geomagnetic local anomalies.

The group-mean corrected directions of $4 \mathrm{~A}$ and $4 \mathrm{~B}$ are distinct at the $5 \%$ significance level, because their $\alpha_{95}$ circles do not overlap (Fig. 8). The group-mean corrected directions of $4 \mathrm{~A}$ and $4 \mathrm{~T}$ are not contained within the $\alpha_{95}$ circle of the other group-mean, but the circles overlap only a little. On the other hand, the group-mean corrected direction of $4 \mathrm{~B}$ is not distinguishable from that of $4 \mathrm{~T}$, because the groupmean corrected direction of $4 \mathrm{~T}$ falls within the $\alpha_{95}$ circle of 4B. Watanabe (1978) reported that the surface of the subunit (the Benri scoria-flow) directly under 4T (the Tosu orange pumice-flow) was slightly weathered and undulated in many places, although paleo-soil, humus, and a notable erosional hiatus were not found at the boundaries between the other sequential subunits in the Kumamoto district (Fig. 2). This observation suggests that the time interval between 4A and $4 \mathrm{~B}$ (or $4 \mathrm{~T}$ ) was longer than that between $4 \mathrm{~T}$ and $4 \mathrm{~B}$. Therefore, the directional difference between $4 \mathrm{~A}$ and $4 \mathrm{~B}$ (or $4 \mathrm{~T})$ in the area around the source caldera likely originated from ancient geomagnetic secular variation.

Nakajima and Fujii (1995a), Hayashida et al. (1996), and Reynolds (1979) showed that ash-fall deposits in areas distal to the source caldera have DRM directions identical to the TRM directions in welded tuffs nearby the source caldera. This observation indicates nearly simultaneous acquisition of TRM and DRM in correlative units. In this study, the corrected directions of distal ash-flow and co-ignimbrite ashfall samples (AS, PM, PYL; DRM) are also identical to those of proximal welded tuff samples (Aso-4A; TRM) in the Aso-4 tephra. It is therefore likely that DRMs of the ash samples are as reliable as TRMs in the welded tuff samples, and that the DRMs and TRMs represent the geomagnetic field direction at the time of the Aso-4A eruption.

Samples from sites AS1, AS2, AS3, AS4, AS8, AS9, AS11 and AS13 were collected from water-laid beds, and those of remaining sites in the Aso-4 co-ignimbrite ash-fall deposits were from aeolian beds. Significant differences between the mean corrected directions of the water-laid and aeolian beds in the Aso-4 co-ignimbrite ash-fall deposit were not detected. The mean corrected directions $(N, D m, I m$, $\left.\alpha_{95}, k\right)$ are $8,-1.8^{\circ}, 45.9^{\circ}, 3.4^{\circ}, 264.1$ and $9,-4.3^{\circ}, 47.7^{\circ}$, $3.8^{\circ}, 188.2$, respectively. Nakajima and Fujii (1995a) also reported that a significant difference was not recognized between the paleomagnetic directions of water-laid and aeolian beds of AT. Both water-laid and aeolian beds of the fine-grained ashes are thought to have acquired stable DRMs 


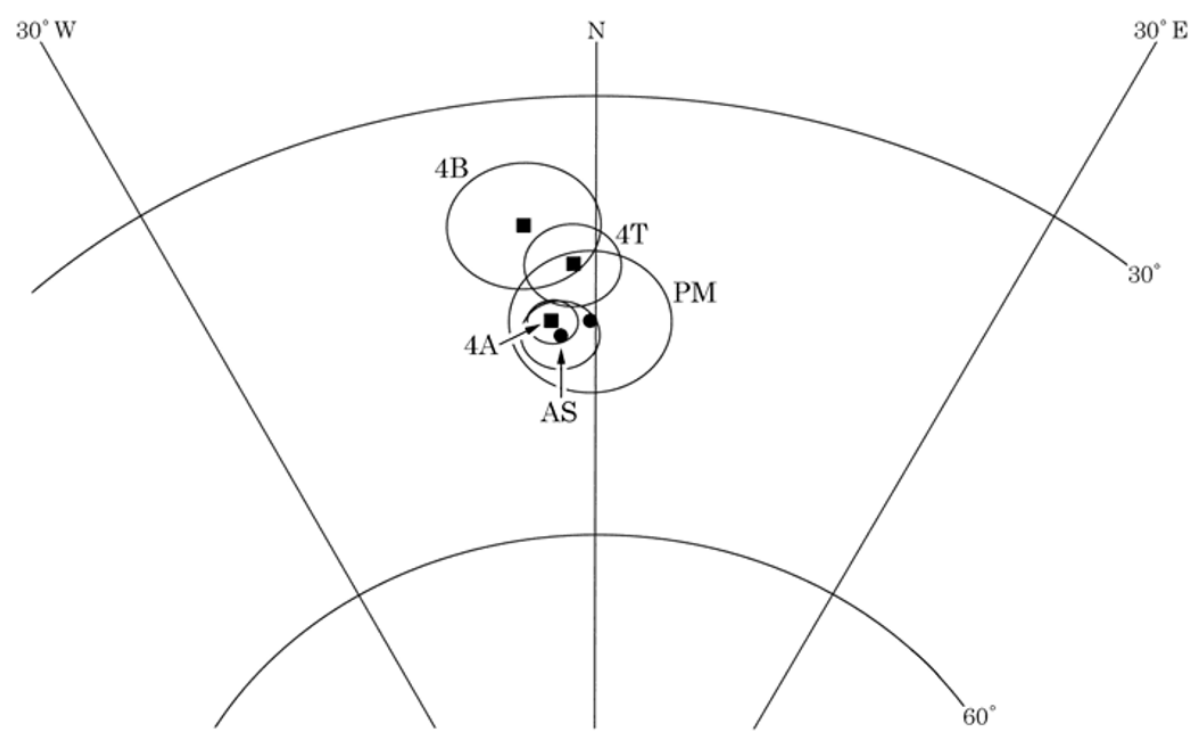

Fig. 8. Equal-area projection of group-mean (4A, 4T, and 4B) and subunit-mean (AS and PM) corrected directions and 95\% confidence circles (lower hemisphere) for the Aso-4 tephra. 4A: Aso-4A, Yame clay, and PYL, 4T: Aso-4T and PYU, 4B: Aso-4B, AS: the Aso-4 co-ignimbrite ash-fall deposit, PM: the Aso-4 distal ash-flow deposit in Miyazaki Prefecture.

A

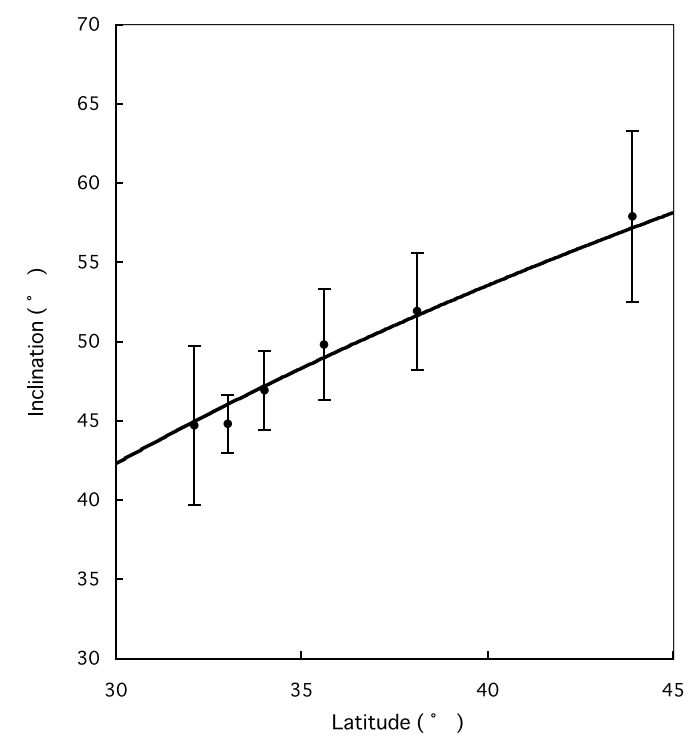

B

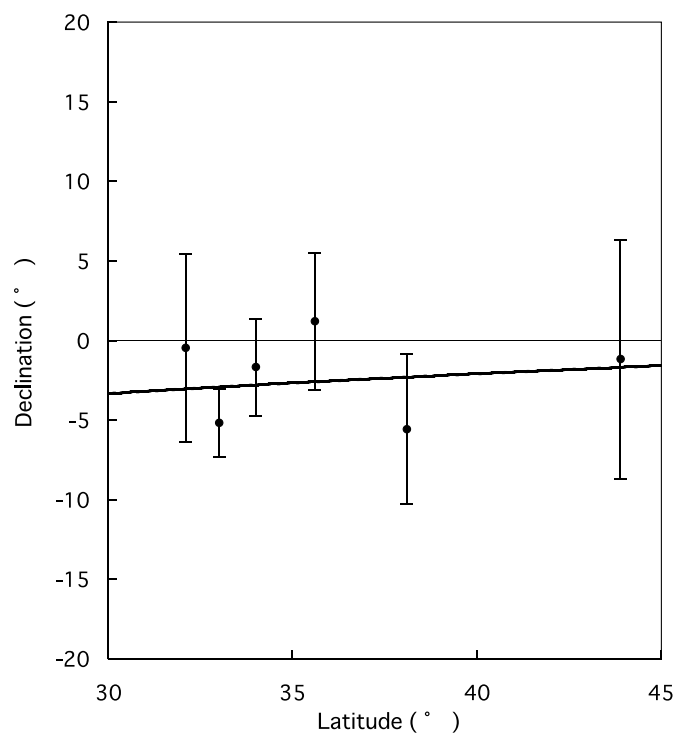

Fig. 9. The relation between mean directions (A: inclinations, B: declinations) and latitudes. Bold lines show the inclinations (A) and declinations (B) expected for the overall-mean VGP $\left(22.7^{\circ} \mathrm{W}, 83.8^{\circ} \mathrm{N}\right)$. The error bars in inclinations and declinations are $\alpha_{95}$ and $\alpha_{95} /$ cos (inclination), respectively.

at approximately the same time as emplacement of the proximal pyroclastic flow.

\section{Geomagnetic Field Over the Japanese Islands at the Time of the Aso-4A Eruption}

Aso-4A, PM, PYL, and AS have identical VGPs (or corrected directions) and were thought to be deposited at the same time. The pyroclastic-flow (Aso-4A) and ash-flow (PM, PYL) deposits are found within $160 \mathrm{~km}$ distance from Aso caldera, and the co-ignimbrite ash-fall deposit (AS) is found 500 to $1,600 \mathrm{~km}$ of from Aso caldera. Figure 9 shows the relation between mean directions and latitudes, which are calculated for central Kyushu (Aso-4A), southern Kyushu (PM), Chugoku (PYL), Chubu (AS1-4, 14, 15), Tohoku (AS5-8, 12, 13, 16, 17), and Hokkaido (AS9-11). The obtained mean directions are almost the same as the expected directions. This fact and the identical VGPs in the near and far regions lead us to believe that these remanent magnetizations were acquired under the same geocentric dipole field coeval with the Aso-4A eruption.

In order to clarify the configuration of the geomagnetic field at the time of the AT eruption (ca. $25 \mathrm{ka}$ ), Nakajima and Fujii (1995a) used the following procedures: (1) the pole of the geomagnetic dipole field was assumed to be located at 


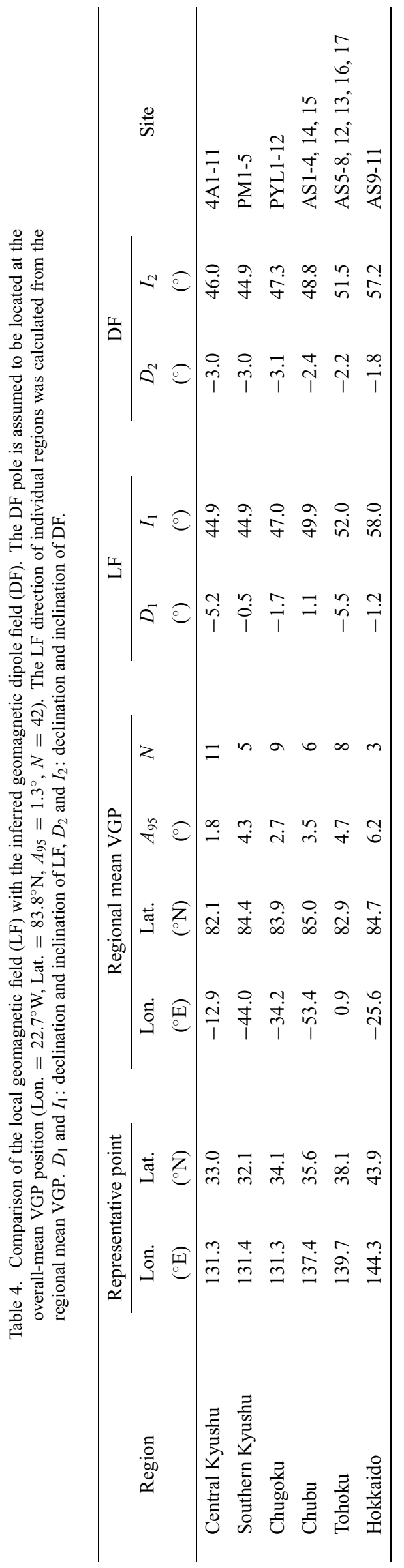


the overall-mean VGP, (2) the direction (declination, inclination) of the dipole field (DF) in each region was calculated using the overall-mean VGP, and (3) the local geomagnetic field (LF) direction was calculated using each regional-mean VGP. By comparing DF and LF at each region, local anomalous directions were found in two regions.

In this study, the DF pole is located at the overall-mean VGP for Aso-4A, PM, PYL, and AS. AS was divided into three regions: Chubu, Tohoku, and Hokkaido. A local anomaly, which exceeds the range of $\alpha_{95}$, could not be detected by comparing the DF and LF in all six regions (Table 4). The reason why the local anomaly was not found in this study might be that the data are too few.

Hyodo et al. (1993) carried out a paleomagnetic study of samples taken from drill cores in the Inland Sea, Lake Yogo, and Lake Kizaki, and presented similar geomagnetic secular variation curves for each region for the last 11,000 years. Moreover, Hayashida et al. (1996) showed that the paleomagnetic directions for two widespread tephras in three distant regions (central Kyushu, Kinki, and the Boso Peninsula) are identical within each correlative unit. These tephras occur at two different horizons dated at about 0.9 Ma and 1.0 $\mathrm{Ma}$; they are the Imaich and Yabakei pyroclastic-flow deposits in central Kyushu which produced widespread coignimbrite ashes that were emplaced in marine and nonmarine sedimentary sequence over distances of up to 1,000 $\mathrm{km}$. On the basis of these earlier paleomagnetic data and those of this study, significant regional differences could not be observed in the configuration of the geomagnetic field throughout the Japanese Islands.

Acknowledgments. We would like to express our cordial thanks first to Prof. Kimio Hirooka of Toyama University for his invaluable suggestions and his continuous encouragement throughout the study. We are indebted to Prof. Isamu Hattori and Associate Prof. Hirofumi Yamamoto of Fukui University, and to the late Mr. Koji Ono for their fruitful suggestions and discussions. We thank Dr. Jonathan T. Hagstrum of U. S. Geological Survey for his critical reading of the manuscript. We also thank Associate Prof. Hidefumi Tanaka of Kochi University and the three anonymous reviewers for their help in improving the manuscript. This study was carried out with the help of many geologists including ex-Prof. Shiro Ishida of Yamaguchi University, Mr. Seiji Matsuo, Mr. Hideo Matsusato, Mr. Hideo Watanabe, Dr. Kiyohide Mizuno of Geological Survey of Japan, Associate Prof. Koji Okumura of Hiroshima University, Prof. Tateo Shiraishi of Akita University, and Associate Prof. Takehiko Suzuki of Tokyo Metropolitan University. This work was partially supported by Grant-in-Aid for Scientific Research by the Ministry of Education, Science, Sports and Culture (No. 12680158).

\section{References}

Endo, H. and Y. Suzuki, Geology of the Tsuma and Takanabe district, with geological sheet map at 1:50,000, Geol. Surv. Japan, 105 pp., 1986 (in Japanese with English abstract).

Fisher, R. A., Dispersion on a sphere, Proc. Roy. Soc., A217, 295-305, 1953.

Fujii, J. and T. Nakajima, Paleomagnetic directions of Quaternary widespread tephras, Mem. Fac. Edu. Fukui Univ., Ser. II, No. 51, 47-60, 1998 (in Japanese with English abstract).

Fujii, J., T. Nakajima, S. Ishida, and S. Matsuo, Paleomagnetic directions of the Aso-4 tephra in Yamaguchi Prefecture, southwest Japan, The Quaternary Res. (Jpn), 39, 227-232, 2000 (in Japanese with English abstract).

Geograph. Surv. Inst. Japan, Isogonic chart for 1990.0, 1900

Gohara, Y., T. Shinbori, K. Suzuki, S. Nomura, and C. Komori, Some problems on the Pleistocene formations of north Kyushu, Japan, Bull. Resource Res. Inst., No. 62, 83-108, 1964 (in Japanese with English abstract).

Hayashida, A., H. Kamata, and T. Danhara, Correlation of widespread tephra deposits based on paleomagnetic directions: link between a volcanic field and sedimentary sequences in Japan, Quaternary International, 34-36, 89-98, 1996.

Hirooka, K., Paleomagnetic and archaeomagnetic age dating, Mem. Geol. Soc. Japan, No. 29, 305-318, 1988 (in Japanese with English abstract).

Hoshizumi, H., K. Ono, K. Mimura, and T. Noda, Geology of the Beppu district, with geological sheet map at 1:50,000, Geol. Surv. Japan, 131 pp., 1988 (in Japanese with English abstract).

Hyodo, M., Recent progress in paleomagnetic and rock-magnetic studies of the Quaternary in Japan, The Quaternary Res. (Jpn), 38, 202-208, 1999.

Hyodo, M. and S. Minemoto, Paleomagnetic dating using geomagnetic secular variations and excursions from lake sediments in Japan, The Quaternary Res. (Jpn), 35, 125-133, 1996 (in Japanese with English abstract).

Hyodo, M., C. Itota, and K. Yaskawa, Geomagnetic secular variation reconstructed from magnetizations of wide-diameter cores of Holocene sediments in Japan, J. Geomag. Geoelectr., 45, 669-696, 1993.

Kamata, H., Geology of the Miyanoharu district, with geological sheet map at 1:50,000, Geol. Surv. Japan, 127 pp., 1997 (in Japanese with English abstract).

Kameyama, T., The Pleistocene formations of the Kammon district, J. Geol. Soc. Japan, 74, 415-426, 1968 (in Japanese with English abstract).

Kawai, N., K. Yaskawa, T. Nakajima, M. Torii, and S. Horie, Oscillating geomagnetic field with a recurring reversal discovered from Lake Biwa, Proc. Japan Acad., 48, 186-190, 1971.

Kimura, K., T. Yoshioka, N. Imoto, S. Tanaka, M. Musashino, and Y. Takahashi, Geology of the Kyoto-Tohokubu district, with geological sheet map at 1:50,000, Geol. Surv. Japan, 89 pp., 1998 (in Japanese with English abstract).

Kirschvink, J. L., The least-squares line and plane and the analysis of paleomagnetic data, Geophys. J. Roy. Astron. Soc., 62, 699-718, 1980.

Lowrie, W., Identification of ferromagnetic minerals in a rock by coercivity and unblocking temperature properties, Geophys. Res. Lett., 17, 159$162,1990$.

Machida, H., Recent progress in tephra studies in Japan, The Quaternary Res. (Jpn), 30, 141-149, 1991.

Machida, H., Quaternary widespread tephra catalog in and around Japan: recent progress, The Quaternary Res. (Jpn), 38, 194-201, 1999.

Machida, H. and F. Arai, Extensive ash falls in and around the Sea of Japan from large late Quaternary eruptions, J. Volcanol. Geotherm. Res., 18, 151-164, 1983.

Machida, H., F. Arai, and M. Momose, Aso-4 ash: a widespread tephra and its implications to the events of late Pleistocene in and around Japan, Bull. Volcanol. Soc. Japan, Ser. 2, 30, 49-70, 1985 (in Japanese with English abstract).

Matsumoto, A., K. Uto, K. Ono, and K. Watanabe, K-Ar age determinations for Aso volcanic rocks - concordance with volcanostratigraphy and application to pyroclastic flows-, Abstracts Fall Meet. in 1991, Volcanol. Soc. Japan, 73, 1991 (in Japanese).

Murayama, M, E. Matsumoto, T. Nakamura, M. Okamura, H. Yasuda, and A. Taira, Re-examination of the eruption age of Air-Tn ash (AT) obtained from a piston core off Shikoku-determined by AMS ${ }^{14} \mathrm{C}$ dating of planktonic foraminifera-, J. Geol. Soc. Japan, 99, 787-798, 1993.

Nakajima, T. and J. Fujii, Paleomagnetic direction of the Aira Tn tephra deposit, The Quaternary Res. (Jpn), 34, 297-307, 1995a (in Japanese with English abstract).

Nakajima, T. and J. Fujii, Magnetic susceptibilities of Quaternary tephras, Mem. Fac. Edu. Fukui Univ., Ser. II, No. 47, 31-46, 1995b (in Japanese with English abstract).

Nakajima, T. and J. Fujii, Paleomagnetic directions of the Aso-4 ash and the Aso pyroclastic flows, The Quaternary Res. (Jpn), 37, 371-383, 1998 (in Japanese with English abstract).

Okumura, K., Quaternary tephra studies in the Hokkaido district, northern Japan, The Quaternary Res. (Jpn), 30, 379-390, 1991 (in Japanese with English abstract)

Ono, K., I. Matsumoto, M. Miyahisa, Y. Teraoka, and N. Kambe, Geology of the Taketa district, with geological sheet map at 1:50,000, Geol. Surv. Japan, 145 pp., 1977 (in Japanese with English abstract).

Reynolds, R. L., Comparison of the TRM of the Yellowstone Group and the DRM of some Pearlette ash beds, J. Geophys. Res., 84, 4525-4532, 1979. 
Sakai, A., Y. Teraoka, K. Miyazaki, H. Hoshizumi, and Y. Sakamaki, Geology of the Miemachi district, with geological sheet map at 1:50,000, Geol. Surv. Japan, 115 p., 1993 (in Japanese with English abstract).

Shiraishi, T., F. Arai, and Y. Fujimoto, Discovery of Aso-4 ash and drift pumice of Aso-4 pyroclastic flow and Sambe-Kisuki pumice fall deposits in the upper Quaternary of the Oga Peninsula, Akita Prefecture, northeast Honshu, Japan, The Quaternary Res. (Jpn), 31, 21-27, 1992 (in Japanese with English abstract).

Suzuki, T., Stratigraphy of middle Pleistocene tephra layers around Nasuno Plain, in north Kanto, central Japan, 102, 73-90, 1993 (in Japanese with English abstract).

Teraoka, Y., K. Okumura, A. Murata, and H. Hoshizumi, Geology of the Saiki district, with geological sheet map at 1:50,000, Geol. Surv. Japan, 78 pp., 1990 (in Japanese with English abstract).

Teraoka, Y., K. Miyazaki, H. Hoshizumi, T. Yoshioka, A. Sakai, and
K. Ono, Geology of the Inukai district, with geological sheet map at 1:50,000, Geol. Surv. Japan, 129 pp., 1992 (in Japanese with English abstract).

Watanabe, K., Studies on the Aso pyroclastic flow deposits in the region to the west of Aso caldera, southwest Japan, I: Geology, Mem. Fac. Edu. Kumamoto Univ., Nat. Sci., No. 27, 97-120, 1978.

Watanabe, H., A. Urabe, and K. Arakawa, Widespread tephras of the Kaisaka terrace deposit in the Tsunan-machi area, Niigata Prefecture Japan, Earth Science (Chikyu Kagaku), 53, 420-433, 1999 (in Japanese with English abstract).

J. Fujii (e-mail: fujii@edu00.f-edu.fukui-u.ac.jp), T. Nakajima (e-mail: nakajima@edu00.f-edu.fukui-u.ac.jp), and H. Kamata (e-mail: kamata@ gaia.h.kyoto-u.ac.jp) 